\title{
Analysis of satellite-derived Arctic tropospheric BrO columns in conjunction with aircraft measurements during ARCTAS and ARCPAC
}

\author{
S. Choi ${ }^{1}$, Y. Wang ${ }^{1}$, R. J. Salawitch ${ }^{2}$, T. Canty ${ }^{2}$, J. Joiner ${ }^{3}$, T. Zeng ${ }^{1}$, T. P. Kurosu ${ }^{4}{ }^{*}$, K. Chance ${ }^{4}$, A. Richter ${ }^{5}$, \\ L. G. Huey ${ }^{1}$, J. Liao ${ }^{1}$, J. A. Neuman ${ }^{6,7}$, J. B. Nowak ${ }^{6,7}$, J. E. Dibb ${ }^{8}$, A. J. Weinheimer ${ }^{9}$, G. Diskin ${ }^{10}$, T. B. Ryerson ${ }^{7}$, \\ A. da Silva ${ }^{3}$, J. Curry ${ }^{1}$, D. Kinnison ${ }^{9}$, S. Tilmes ${ }^{9}$, and P. F. Levelt ${ }^{11,12}$ \\ ${ }^{1}$ Georgia Institue of Technology, Atlanta, GA, USA \\ ${ }^{2}$ University of Maryland College Park, College Park, MD, USA \\ ${ }^{3}$ NASA Goddard Space Flight Center, Greenbelt, MD, USA \\ ${ }^{4}$ Harvard-Smithsonian Center for Astrophysics, Cambridge, MA, USA \\ ${ }^{5}$ Institute of Environmental Physics, University of Bremen, Bremen, Germany \\ ${ }^{6}$ Cooperative Institute for Research in Environmental Sciences (CIRES), \\ University of Colorado Boulder, Boulder, CO, USA \\ ${ }^{7}$ NOAA Earth System Research Laboratory, Boulder, CO, USA \\ ${ }^{8}$ University of New Hampshire, Durham, NH, USA \\ ${ }^{9}$ National Center for Atmospheric Research, Boulder, CO, USA \\ ${ }^{10}$ NASA Langley Research Center, Hampton, VA, USA \\ ${ }^{11}$ Royal Netherlands Meteorological Institute (KNMI), De Bilt, The Netherlands \\ ${ }^{12}$ University of Technology Eindhoven, Eindhoven, The Netherlands \\ *now at: NASA Jet Propulsion Laboratory, Pasadena, CA, USA
}

Correspondence to: S. Choi (sungyeon.choi@eas.gatech.edu)

Received: 17 August 2011 - Published in Atmos. Chem. Phys. Discuss.: 21 September 2011

Revised: 3 January 2012 - Accepted: 13 January 2012 - Published: 1 February 2012

\begin{abstract}
We derive tropospheric column $\mathrm{BrO}$ during the ARCTAS and ARCPAC field campaigns in spring 2008 using retrievals of total column $\mathrm{BrO}$ from the satellite $\mathrm{UV}$ nadir sensors OMI and GOME-2 using a radiative transfer model and stratospheric column $\mathrm{BrO}$ from a photochemical simulation. We conduct a comprehensive comparison of satellitederived tropospheric $\mathrm{BrO}$ column to aircraft in-situ observations of $\mathrm{BrO}$ and related species. The aircraft profiles reveal that tropospheric $\mathrm{BrO}$, when present during April 2008, was distributed over a broad range of altitudes rather than being confined to the planetary boundary layer (PBL). Perturbations to the total column resulting from tropospheric $\mathrm{BrO}$ are the same magnitude as perturbations due to longitudinal variations in the stratospheric component, so proper accounting of the stratospheric signal is essential for accurate determination of satellite-derived tropospheric $\mathrm{BrO}$. We find reasonably good agreement between satellite-derived tropospheric $\mathrm{BrO}$ and columns found using aircraft in-situ $\mathrm{BrO}$ profiles, particularly when satellite radiances were obtained
\end{abstract}

over bright surfaces (albedo $>0.7$ ), for solar zenith angle $<80^{\circ}$ and clear sky conditions. The rapid activation of $\mathrm{BrO}$ due to surface processes (the bromine explosion) is apparent in both the OMI and GOME-2 based tropospheric columns. The wide orbital swath of OMI allows examination of the evolution of tropospheric $\mathrm{BrO}$ on about hourly time intervals near the pole. Low surface pressure, strong wind, and high PBL height are associated with an observed $\mathrm{BrO}$ activation event, supporting the notion of bromine activation by high winds over snow.

\section{Introduction}

Bromine plays an important role in tropospheric ozone chemistry and the resulting oxidation capacity of the polar boundary layer. Bromine radicals catalytically destroy ozone, leading to nearly complete removal near the surface that is termed an ozone $\left(\mathrm{O}_{3}\right)$ depletion event (ODE). Once $\mathrm{O}_{3}$ is

Published by Copernicus Publications on behalf of the European Geosciences Union. 
depleted, high levels of reactive halogen species including atomic bromine (e.g. Br) become the primary oxidants for many species, including methane $\left(\mathrm{CH}_{4}\right)$ and mercury $(\mathrm{Hg})$ (e.g. Simpson et al., 2007b; Schroeder et al., 1998). During mercury depletion events (MDEs), $\mathrm{Br}$ and $\mathrm{BrO}$ are thought to oxidize elemental mercury to more reactive gaseous mercury that deposit to the polar ecosystem (Schroeder et al., 1998; Lu et al., 2001; Ariya et al., 2004; Douglas et al., 2005; Holmes et al., 2010).

A primary source of active bromine in the polar boundary layer is thought to be bromide $\left(\mathrm{Br}^{-}\right)$in the condensed phase, which is transformed to gaseous molecular bromine $\left(\mathrm{Br}_{2}\right)$ by heterogenous chemistry. Potential sources of bromide are sea salt aerosols (Fan and Jacob, 1992), surfaces of first year sea ice (Simpson et al., 2007a; Wagner et al., 2007) or newly formed sea ice (Jones et al., 2006), frost flowers (Kaleschke et al., 2004), or blowing snow triggered by strong winds (Yang et al., 2008; Jones et al., 2009, 2010; Begoin et al., 2010; Theys et al., 2011; Toyota et al., 2011). $\mathrm{Br}_{2}$ released to the atmosphere is rapidly photolyzed to yield bromine radicals $(\mathrm{Br})$, i.e.

$$
\begin{aligned}
& \mathrm{HOBr}+\mathrm{Br}^{-}+\mathrm{H}^{+} \rightleftharpoons \mathrm{H}_{2} \mathrm{O}+\mathrm{Br}_{2} \text { (condensed phase) } \\
& \mathrm{Br}_{2}+\mathrm{h} v \rightarrow 2 \mathrm{Br} \text { (gas phase). }
\end{aligned}
$$

The bromine radicals then lead to catalytic ozone loss, i.e.

$$
\begin{aligned}
& \mathrm{Br}+\mathrm{O}_{3} \rightarrow \mathrm{BrO}+\mathrm{O}_{2} \\
& \mathrm{BrO}+\mathrm{XO} \rightarrow \mathrm{BrX}+\mathrm{O}_{2}(\mathrm{X}=\mathrm{Br}, \mathrm{Cl}, \mathrm{I}, \text { and } \mathrm{OH}) \\
& \mathrm{BrX}+\mathrm{h} v \rightarrow \mathrm{Br}+\mathrm{X}
\end{aligned}
$$

Barrie et al. (1988) found that filterable bromine is strongly anti-correlated with the abundance of $\mathrm{O}_{3}$ in the polar boundary layer. Following this work, many additional measurements of bromine species along with $\mathrm{O}_{3}$ have been made in polar environments (e.g. Bottenheim et al., 1990; Barrie et al., 1994; Hausmann and Platt, 1994; Tuckermann et al., 1997; Martinez et al., 1999; Ridley et al., 2003). The association of elevated $\mathrm{BrO}$ and depleted surface $\mathrm{O}_{3}$ during Arctic spring is well established (e.g. Platt and Hönninger, 2003, and references therein).

Bromine monoxide $(\mathrm{BrO})$, an intermediate in the catalytic loss of ozone, is the most commonly observed active bromine species. $\mathrm{BrO}$ absorbs ultraviolet (UV) radiation, which enables measurement using remote sensing techniques. Reported in-situ and remotely-sensed ground-, balloon-, and aircraft-based $\mathrm{BrO}$ measurements include: (1) boundary layer mixing ratio with Long Path-Differential Optical Absorption Spectroscopy (LP-DOAS) (Hausmann and Platt, 1994; Tuckermann et al., 1997; Martinez et al., 1999); (2) mixing ratio by aircraft in-situ Chemical-Ionization Mass Spectrometry (CIMS) (Neuman et al., 2010; Liao et al., 2011a,b); (3) boundary layer and free tropospheric BrO column using DOAS on aircraft (McElroy et al., 1999; PradosRoman et al., 2011); (4) total, stratospheric, and tropospheric columns using ground-based zenith sky and direct sun DOAS (Frieß et al., 1999; Schofield et al., 2004, 2006; Hendrick et al., 2007, 2008; Theys et al., 2007); (5) boundary-layer column with ground-based MAX-DOAS (Hönninger, 2004; Simpson et al., 2007a; Donohoue et al., 2010; Frieß et al., 2011); (6) balloon profiles using a variety of spectroscopic methods (Fitzenberger et al., 2000; Pfeilsticker et al., 2000; Pundt et al., 2002; Dorf et al., 2008). Despite the many measurements of $\mathrm{BrO}$ and related species obtained by various techniques, significant uncertainties remain regarding the importance of very short lived source compounds on the stratospheric bromine budget (e.g. Sect. 1.3.3.3 of WMO, 2011) as well as the magnitude of the global, ubiquitous, background level of tropospheric BrO (e.g. Sect. 5.3 of Theys et al., 2011).

Space-based observation of $\mathrm{BrO}$ offers an excellent tool for studying Arctic polar bromine chemistry. Satellite observations provide global coverage, far superior to the spatial coverage available from ground- and aircraft-based measurements. Limb-sounding observations from the Microwave Limb Sounder (MLS) (Livesey et al., 2006; Kovalenko et al., 2007) provide quantification of $\mathrm{BrO}$ profiles in the upper and middle stratosphere. The MLS observations of $\mathrm{BrO}$ imply a significant contribution to stratospheric bromine from sources other than long-lived $\mathrm{CH}_{3} \mathrm{Br}$ and halons. Limb observations from the SCanning Image Absorption SpectroMeter for Atmospheric CHartographY (SCIAMACHY) (Sinnhuber et al., 2005; Sioris et al., 2006; Rozanov et al., 2011) extend into the lowermost stratosphere (LMS) and nadir measurements from SCIAMACHY constrain total column $\mathrm{BrO}$, including contributions from the stratosphere and troposphere. The retrievals of SCIAMACHY BrO by Rozanov et al. (2011) and Sinnhuber et al. (2005) imply a limited role for supply of bromine by very short lived (VSL) compounds to the LMS and a considerable burden of global, ubiquitous, background $\mathrm{BrO}$ whereas the retrieval of SCIAMACHY BrO described by Sioris et al. (2006) implies a larger role for supply of stratospheric inorganic bromine, $\mathrm{Br}_{\mathrm{y}}$, by VSL compounds and a much smaller level for background tropospheric $\mathrm{BrO}$ (e.g. Sect. 2.5.2.1 of WMO, 2007).

Nadir-viewing instruments on polar-orbiting satellites provide multiple daily observations of total column $\mathrm{BrO}$ at high latitude. The high surface albedo of polar regions provides good sensitivity to tropospheric $\mathrm{BrO}$, including that near the surface (Wagner and Platt, 1998; Theys et al., 2011). Chance (1998) and Hegels et al. (1998) retrieved BrO total vertical column densities (VCD) from nadir radiances in the UV obtained by Global Ozone Monitoring Experiment (GOME) (GOME Users Manual, 1995) on the European Space Agency (ESA) European Remote Sensing 2 (ERS2) satellite. The early GOME observations showed large enhancements over Hudson Bay during spring 1997, which was attributed to bromine release from the surface (Chance, 1998). Estimates of $\mathrm{BrO}$ total column amount have been subsequently derived from other nadir-viewing satellite sensors 
including the Ozone Monitoring Instrument (OMI) (Levelt et al., 2006) on the US National Aeronautics and Space Administration (NASA) Aura satellite, SCIAMACHY (Bovensmann et al., 1999) on the ESA Environmental Satellite (EnviSat), and the second Global Ozone Monitoring Experiment (GOME-2) instruments (Munro et al., 2006) that are flying on the series of European Meteorological Operational Satellites (EuMetSat MetOp). Retrievals of VCD BrO from different satellite instruments and by various groups tend to be in fairly close agreement. All satellite instruments report levels of BrO considerably larger than predicted by models that account only for stratospheric supply from the decomposition of methyl bromide and halons. The focus of the scientific community since publication of early GOME observations has been quantifying the degree to which this "excess BrO" resides in the troposphere, the stratosphere, or perhaps both regions of the atmosphere.

Tropospheric $\mathrm{BrO}$ columns can be derived from satellite observations using the residual method, in which an estimate of the stratospheric $\mathrm{BrO}$ column is subtracted from the satellite-derived VCD of BrO. Wagner and Platt (1998) and Richter et al. (1998) estimated tropospheric VCD of BrO using this approach from GOME observations, based on simple assumptions for stratospheric $\mathrm{BrO}$. These studies and many others assumed that stratospheric $\mathrm{BrO}$ is zonally symmetric and that bromine was supplied to the stratosphere solely by the decomposition of long-lived organic compounds. Theys et al. (2009) and Salawitch et al. (2010) showed that the stratospheric $\mathrm{VCD}$ of $\mathrm{BrO}$ can exhibit strong gradients with respect to longitude at high latitude during spring and Salawitch et al. (2010) questioned prior estimates of residual tropospheric $\mathrm{BrO}$ found assuming that the stratospheric burden was zonally symmetric. Theys et al. (2011) derived tropospheric BrO columns from GOME-2 spectra with a modelbased stratospheric $\mathrm{BrO}$ climatology (Theys et al., 2009) similar to that used here and described below.

Many studies related to bromine and ozone chemistry have been conducted using satellite-derived tropospheric BrO columns. Wagner and Platt (1998) reported elevated regions of $\mathrm{BrO}$ vertical column density in the Arctic and Antarctic regions. They noted these enhancements were likely due to increased abundance of tropospheric $\mathrm{BrO}$, rather than a stratospheric disturbance, based on a variety of factors including the correlation between enhanced columns of $\mathrm{BrO}$ and the $\mathrm{O}_{2}-\mathrm{O}_{2}$ collision complex. Wagner et al. (2001) showed that elevated $\mathrm{BrO}$ column amounts observed by GOME were correlated with low ozone in the boundary layer observed in-situ at Ny-Ålesund (Spitsbergen), Norway. In other studies, spatial and temporal features of ODEs have been simulated using 3-dimensional regional chemical transport models and GOME-derived tropospheric $\mathrm{BrO}$ columns (Zeng et al., 2003, 2006). Connections between BrO-rich air masses and first-year sea ice have been indicated with backtrajectory analyses using SCIAMACHY data (Wagner et al., 2007). Transport of a large BrO plume near the North Pole is also reported by Begoin et al. (2010). A back trajectory study using satellite-derived tropospheric $\mathrm{BrO}$ columns indicated that ODEs can be differentiated into locally activated and transport driven events (Koo et al., 2012).

Despite the numerous studies of tropospheric polar bromine chemistry using satellite $\mathrm{BrO}$ observations, estimation and interpretation of tropospheric $\mathrm{BrO}$ information from space presents ongoing challenges. To properly estimate tropospheric $\mathrm{BrO}$ column amounts, the stratospheric contribution to the satellite-derived total column must be accurately represented (e.g. Theys et al., 2009; Salawitch et al., 2010). The global, ubiquitous background tropospheric level of $\mathrm{BrO}$ inferred from the satellite record is sensitive to the amount of $\mathrm{Br}_{\mathrm{y}}$ delivered to the stratosphere by VSL bromocarbons (Salawitch et al., 2005). Furthermore, low solar elevation angles in the early polar spring lead to large uncertainties in satellite total $\mathrm{BrO}$ column retrievals (see below). The presence of clouds further complicates the retrieval of tropospheric $\mathrm{BrO}$ from satellite observations. Theys et al. (2011) have recently addressed many of these issues. They showed maps of tropospheric $\mathrm{BrO}$ columns derived using a method similar to that described below, and evaluated these columns using ground-based measurements of the tropospheric and stratospheric contributions to the total column. Our study builds upon the work of Theys et al. (2011) by further exploring the issues that affect quantification of tropospheric $\mathrm{BrO}$ columns and by using aircraft measurements of $\mathrm{BrO}$ to evaluate the satellite-derived tropospheric columns.

Salawitch et al. (2010) provided an initial analysis of $\mathrm{BrO}$ observations obtained by instruments aboard the NASA and NOAA aircraft (Neuman et al., 2010; Liao et al., 2011b) and the OMI satellite instrument (Kurosu and Chance, 2011) during spring 2008. They simulated the stratospheric BrO column assuming VSL bromocarbons supply between 5 and $10 \mathrm{ppt}$ of $\mathrm{Br}_{\mathrm{y}}$ to the stratosphere in the form of product gas injection (PGI), in addition to the $\sim 2 \mathrm{ppt}$ of $\mathrm{Br}_{\mathrm{y}}$ supplied by source gas injection (SGI) of the VSL species $\mathrm{CH}_{2} \mathrm{Br}_{2}$. On the other hand, Theys et al. (2011) simulated the stratospheric burden of $\mathrm{BrO}$ assuming 1 ppt of PGI and 5 ppt of SGI (all represented as $\mathrm{CH}_{2} \mathrm{Br}_{2}$ ). The stratospheric $\mathrm{BrO}$ burden found by Salawitch et al. (2010) for their "best case" simulation of $7 \mathrm{ppt}$ from PGI and 2 ppt from SGI (see their Fig. S7) is considerably larger ( $\sim 27 \%$ overall difference, with quite a bit of geographic variability) than the stratospheric BrO burden used by Theys et al. (2011) as shown in Fig. S1. Although we do not compare to independent observations of $\mathrm{BrO}$ here, such comparisons to aircraft and balloon-borne observations of $\mathrm{BrO}$ in Salawitch et al. (2005) support the use of our values for the delivery of stratospheric bromine by PGI and SGI. Other observations of $\mathrm{BrO}$, such as some of those discussed in Sect. 2.5.2 of WMO (2007), support smaller values for these parameters.

Salawitch et al. (2010) concluded that high column amounts of $\mathrm{BrO}$ derived from satellite observations could, in some cases, be attributed to compression of stratospheric 
air to low altitudes (high pressures) and that this condition, not previously recognized in the analysis of the satellite $\mathrm{BrO}$ record, should be considered to properly relate the satellite record to surface events. The magnitude of the stratospheric enhancement is sensitive to the supply of stratospheric $\mathrm{Br}_{\mathrm{y}}$ from VSL bromocarbons as well as the pathways of this transport (i.e. PGI versus SGI; see Chapter 2 of WMO (2003) for a detailed discussion of these pathways). Salawitch et al. (2010) showed agreement, to within uncertainties, between total column BrO measured by OMI and the sum of modeled stratospheric and aircraft-measured tropospheric $\mathrm{BrO}$ partial columns. However, their treatment of the tropospheric column did not explicitly account for tropospheric air mass factors (AMFs) and thus must be viewed with caution. Our study builds on this prior work by using a radiative transfer model to calculate tropospheric AMFs and also by considering the effects of clouds, surface reflectivity, and viewing geometry on the evaluation of the bromine budget for Arctic spring 2008.

Validation of satellite-derived $\mathrm{BrO}$ columns and their relationship to ODEs was a goal of two Arctic field campaigns conducted in 2008 under the auspices of the International Polar Year (IPY). The Arctic Research of the Composition of the Troposphere from Aircraft and Satellite (ARCTAS) mission was conducted in April and June-July 2008 by NASA (Jacob et al., 2010) and the US National Oceanic and Atmospheric Administration (NOAA) Aerosol, Radiation, and Cloud Processes affecting Arctic Climate (ARCPAC) mission took place in April 2008 (Brock et al., 2011). Various in-situ aircraft measurements of trace chemicals, including $\mathrm{O}_{3}$ and reactive bromine species $\left(\mathrm{BrO}, \mathrm{Br}_{2}\right.$, and soluble bromide), were made during these campaigns. Neuman et al. (2010) and Liao et al. (2011a) provide an overview of the insitu measurements of $\mathrm{BrO}$ and related species obtained during ARCTAS and ARCPAC.

\section{Data description}

We use a variety of aircraft and satellite measurements and model outputs to calculate and evaluate satellite-derived tropospheric $\mathrm{BrO}$ columns. Tropospheric $\mathrm{BrO}$ columns are inferred from aircraft measurements of in-situ $\mathrm{BrO}$ (henceforth referred to as "in-situ columns", as described in Sect. 2.1). We derive tropospheric vertical column densities (VCDs) using $\mathrm{BrO}$ slant column densities (SCD) retrieved from OMI and GOME-2 (see Sect. 2.2) and a model simulation of the stratospheric BrO column as detailed in Sect. 2.3. OMI rotational Raman scene pressures and MODIS cloud products (see Sect. 2.4) are used to assess cloud effects on the derived tropospheric $\mathrm{BrO}$ columns. Data from a global reanalysis, described in Sect. 2.5, are used to examine relationships between observed $\mathrm{BrO}$ enhancement events and meteorological conditions.
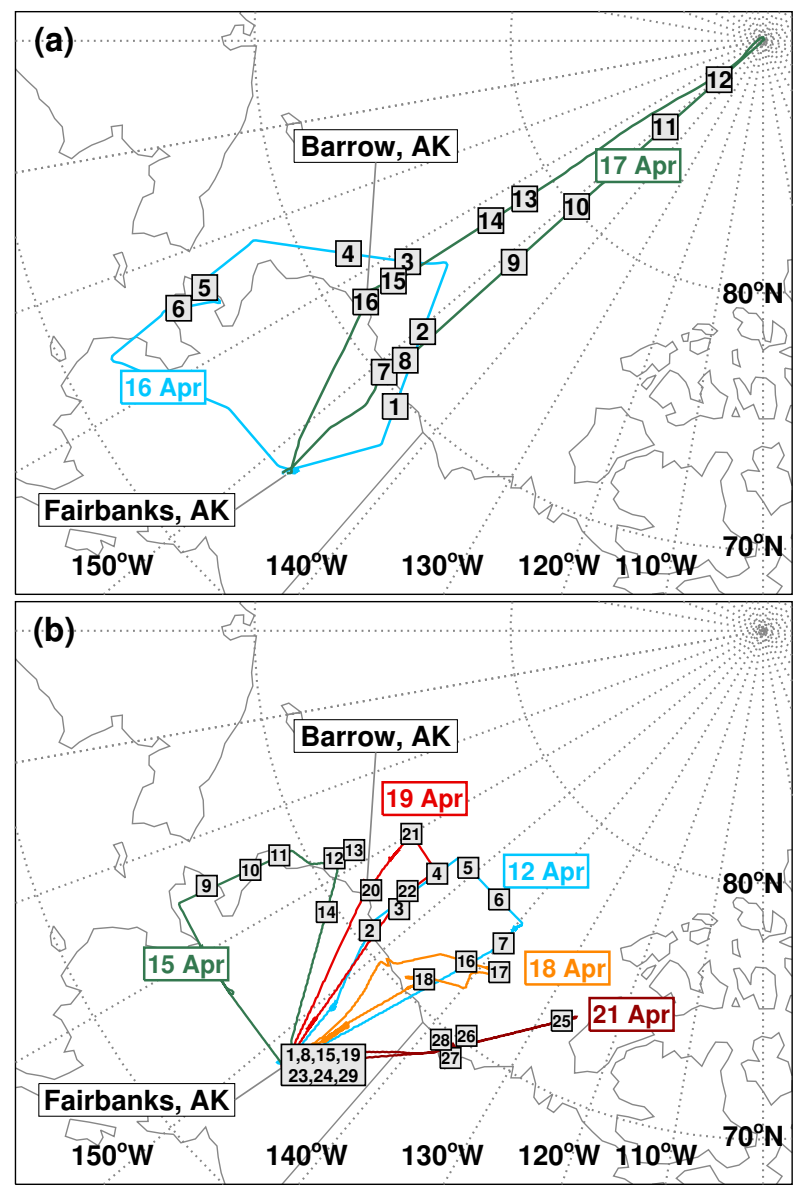

Fig. 1. Flight tracks (lines) and the locations (numbers) of BrO profiles measured by instruments on board the (a) NASA DC-8 aircraft during ARCTAS and (b) NOAA WP-3D aircraft during ARCPAC.

\subsection{Aircraft in-situ measurements}

Aircraft in-situ measurements of $\mathrm{BrO}$ and various other trace gas concentrations were made from the NASA DC-8 aircraft during ARCTAS and the NOAA WP-3D aircraft during ARCPAC. An overview of the instruments, flights, and mission goals and accomplishments are provided in the ARCTAS (Jacob et al., 2010) and ARCPAC (Brock et al., 2011) overview papers. BrO was measured using Chemical Ionization Mass Spectrometer (CIMS) instruments during both experiments (Neuman et al., 2010; Liao et al., 2011b).

DC-8 CIMS measurements of $\mathrm{BrO}$ were made once every $30 \mathrm{~s}$, and WP-3D CIMS measurements were acquired once every $2 \mathrm{~s}$. Measurement uncertainties for $\mathrm{BrO}$ are $\pm 40 \%$ with a detection limit of 3 pptv for WP-3D data and $\pm 40 \%$ and a detection limit of 2-5 pptv for DC-8 data (Neuman et al., 2010; Liao et al., 2011b). In this study, we use $1 \mathrm{~min}$ averaged data for both DC-8 and WP-3D measurements. The spatial resolution of the 1 min averaged aircraft data is approximately $10 \mathrm{~km}$. 

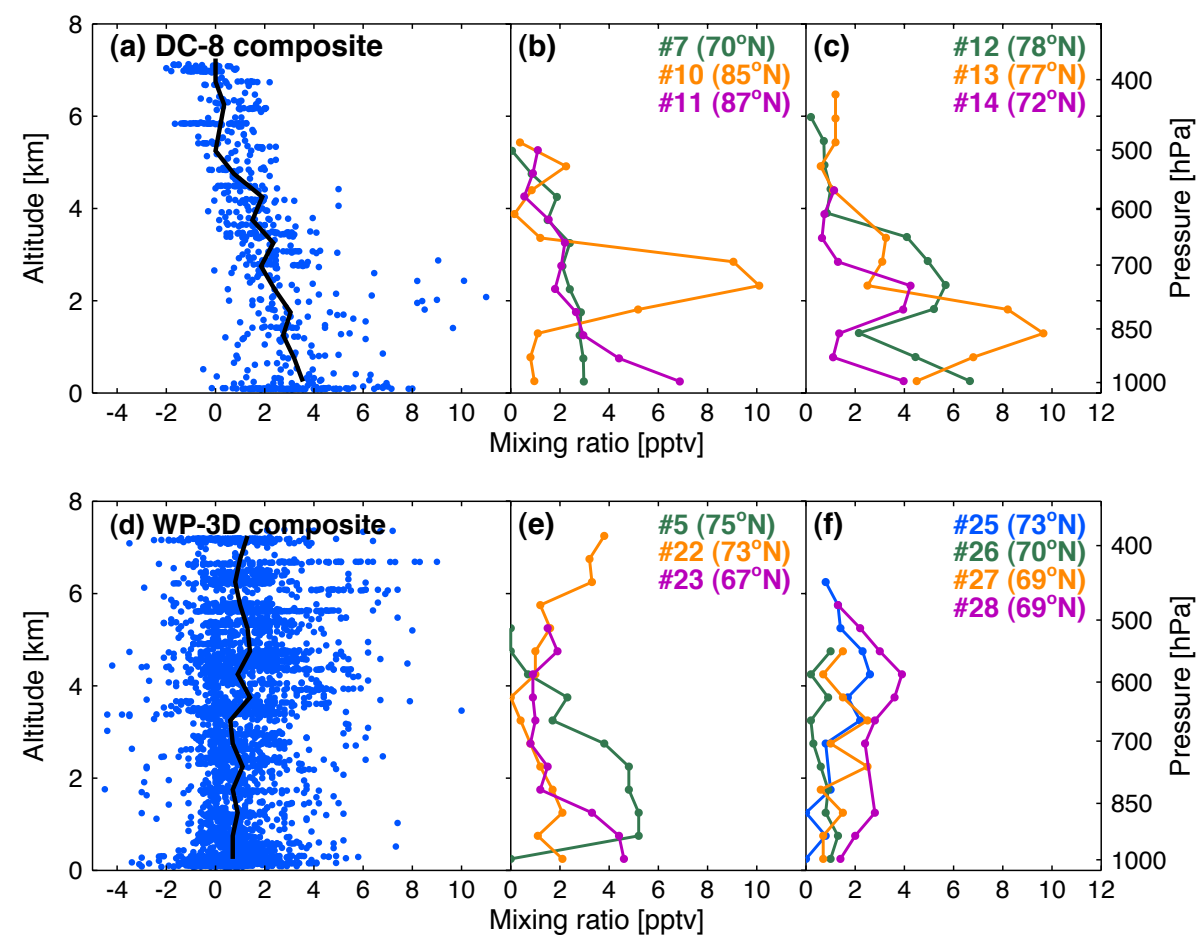

Fig. 2. (a) Collection of DC- 8 measurements of $\mathrm{BrO}$ (blue dots) and DC- 8 composite BrO profile (black line) and (b) DC-8 BrO profiles \#7, $\# 10$, and \#11, (c) DC-8 BrO profiles \#12, \#13, and \#14, (d) similar to (a) but for WP-3D measurements of BrO, (e) WP-3D BrO profiles \#5, $\# 22$, and \#23, (f) WP-3D BrO profiles \#25, \#26, \#27, and \#28.

We estimate tropospheric $\mathrm{BrO}$ columns from the aircraft $\mathrm{BrO}$ mixing ratio measurements for each ascent and descent. Figure 1 shows the flight tracks and locations of the 16 (29) profiles made from the DC-8 (WP-3D). BrO profiles are available for 16 and 17 April 2008 from the DC-8 and 12, 15, 18, 19 and 21 April 2008 from the WP-3D. We also examine measurements of other quantities for DC- 8 flights of 5 and 8 April 2008, for which $\mathrm{BrO}$ was below the instrument detection limit. To calculate tropospheric columns from the aircraft data, the profiles were binned on an altitude grid with $500 \mathrm{~m}$ resolution from the surface to $7.5 \mathrm{~km}$ ( $\mathrm{BrO}$ measurements are available only up to $7.5 \mathrm{~km}$ altitude). For each bin, the median value was selected as the $\mathrm{BrO}$ mixing ratio at that altitude. If the median value was less than 0 , then we assumed the mixing ratio was 0 .

This sampling strategy was chosen to properly represent the signature of the ARCTAS and ARCPAC BrO profiles, which show that the tropospheric column is domimated by contributions from above the top of the convective boundary layer (i.e., the region of constant potential temperature; see Neuman et al. (2010) and Salawitch et al. (2010)) and, when $\mathrm{BrO}$ enhancements occur, they are present in relatively thick altitude segments (i.e., extent larger than $500 \mathrm{~m}$ ). Our results are insensitive to use of mean $\mathrm{BrO}$ within the layers rather than median $\mathrm{BrO}$.
Figure 2a shows the entire collection of DC-8 BrO measurements and the median DC-8 (henceforth referred to as the composite) profile. Figure $2 b$ and $c$ shows samples of different types of DC-8 $\mathrm{BrO}$ profiles collected during April 2008. Among the 16 DC- 8 BrO profiles, 8 have shapes similar to the DC- 8 composite profile, while the others show elevated $\mathrm{BrO}$ near the surface and/or in layers at altitudes from 2 to $4 \mathrm{~km}$. WP-3D measurements of BrO exhibit larger variability than those from the DC-8 (Fig. 2d, e, and f).

The DC-8 and WP-3D instruments reported much lower mixing ratios of $\mathrm{BrO}$ near the surface than have been measured in the past by LP-DOAS instruments in the springtime Arctic boundary layer (Hausmann and Platt, 1994; Tuckermann et al., 1997; Martinez et al., 1999). The median value of surface $\mathrm{BrO}$ at Barrow, Alaska $\left(71^{\circ} \mathrm{N}, 156^{\circ} \mathrm{W}\right)$ during spring 2009 was measured to be $\sim 4$ ppt by a CIMS instrument and $\sim 8$ ppt by a DOAS instrument (Fig. S2). We have no reason to suspect that conditions during spring 2008 were appreciably different than conditions during spring 2009. The low values of $\mathrm{BrO}$ observed during ARCTAS and ARCPAC could be due to preferential sampling of $\mathrm{O}_{3}$ depleted air by the two aircraft (which would titrate inorganic bromine from $\mathrm{BrO}$ to $\mathrm{Br}$ ) or the fact the aircraft generally sampled to an altitude of $100 \mathrm{~m}$ above the surface (Neuman et al., 2010). While it is tempting to argue that perturbations to the $\mathrm{BrO}$ profile due to surface release are confined to the lowest region 
Table 1. Information for NASA DC-8 BrO profiles shown in Fig. 1. "Day" means day of April 2008. Alt (Alt $_{\mathrm{T}}$ ) means the bottom (top) altitude of the profile. "Col." stands for BrO vertical column density (VCD). Units of BrO VCD are $10^{13}$ molecules cm ${ }^{-2}$. "Col.ADDED" is the estimated amount of $\mathrm{BrO}$ that was added to the measured in-situ column to provide an estimate of the complete tropospheric column.

\begin{tabular}{rrrrrrrrrr}
\hline No. & Day & UTC & $\begin{array}{r}\text { Lat. } \\
{\left[{ }^{\circ}\right]}\end{array}$ & $\begin{array}{r}\text { Lon. } \\
{\left[{ }^{\circ}\right]}\end{array}$ & $\begin{array}{r}\text { Alt } \\
{[\mathrm{m}]}\end{array}$ & $\begin{array}{r}\text { Alt } \\
{[\mathrm{km}]}\end{array}$ & $\begin{array}{r}H_{\mathrm{TRP}} \\
{[\mathrm{km}]}\end{array}$ & $\begin{array}{r}\text { Col. } \\
\text { IN-SITU }\end{array}$ & $\begin{array}{r}\text { Col. } \\
\text { ADDED }\end{array}$ \\
\hline 1 & 16 & $20: 52$ & 69.7 & -145.3 & 95 & 4.2 & 7.6 & 4.36 & $5.3 \%$ \\
2 & 16 & $21: 17$ & 71.1 & -147.4 & 82 & 4.2 & 7.0 & 2.85 & $8.1 \%$ \\
3 & 16 & $22: 17$ & 73.2 & -159.0 & 89 & 4.0 & 6.9 & 3.97 & $5.8 \%$ \\
4 & 16 & $22: 34$ & 72.1 & -161.9 & 105 & 3.6 & 7.3 & 2.14 & $27.4 \%$ \\
5 & 16 & $23: 44$ & 66.3 & -165.5 & 206 & 4.1 & 7.0 & 3.04 & $7.6 \%$ \\
6 & 16 & $24: 06$ & 65.2 & -165.2 & 387 & 4.2 & 9.3 & 2.87 & $8.0 \%$ \\
7 & 17 & $21: 34$ & 70.3 & -148.7 & 75 & 5.2 & 8.0 & 2.68 & $3.9 \%$ \\
8 & 17 & $21: 53$ & 71.0 & -148.2 & 83 & 6.3 & 8.1 & 2.18 & $22.4 \%$ \\
9 & 17 & $22: 51$ & 77.1 & -148.4 & 99 & 6.3 & 7.4 & 3.86 & $0.3 \%$ \\
10 & 17 & $23: 29$ & 80.3 & -148.4 & 90 & 5.5 & 8.2 & 3.44 & $1.1 \%$ \\
11 & 17 & $24: 13$ & 84.9 & -148.5 & 112 & 5.4 & 7.3 & 3.04 & $3.4 \%$ \\
12 & 17 & $24: 40$ & 87.2 & -148.4 & 112 & 5.9 & 6.3 & 4.35 & $0.8 \%$ \\
13 & 17 & $26: 58$ & 78.3 & -156.5 & 89 & 7.0 & 7.7 & 5.20 & $3.7 \%$ \\
14 & 17 & $27: 15$ & 77.1 & -156.6 & 89 & 4.5 & 7.5 & 2.57 & $9.0 \%$ \\
15 & 17 & $28: 15$ & 71.8 & -157.5 & 90 & 4.1 & 6.6 & 2.11 & $23.2 \%$ \\
16 & 17 & $28: 35$ & 71.3 & -156.8 & 75 & 5.8 & 8.2 & 1.88 & $10.6 \%$ \\
\hline
\end{tabular}

of the marine boundary layer (a region inaccessible to the two aircraft), ground-based MAX-DOAS observations from Barrow, Alaska obtained during April 2008 suggest that when $\mathrm{BrO}$ was elevated, the perturbation extended to $\sim 1 \mathrm{~km}$ altitude (Salawitch et al., 2010). In contrast, MAX-DOAS near Barrow obtained during April 2009 by another group suggest the enhancement to BrO usually occurs in the lowest $300 \mathrm{~m}$, with one case where elevated $\mathrm{BrO}$ extended to $500 \mathrm{~m}$ altitude (Frieß et al., 2011). A retrieval of the BrO profile using radiances measured in the Arctic during April 2007 by an airborne limb scanning mini-DOAS instrument also suggest elevated $\mathrm{BrO}$ is confined to the boundary layer (Prados-Roman et al., 2011). The ARCTAS and ARCPAC in-situ profiles of $\mathrm{BrO}$ show, consistent with MAX-DOAS data from April 2008 , that the highest mixing ratios of $\mathrm{BrO}$ tended to be observed above the boundary layer. Nonetheless, the profiles of $\mathrm{BrO}$ shown in Fig. 2 almost certainly reflect admixtures of air that has been influenced by recent surface release of active bromine with air that has achieved a background level of $\mathrm{BrO}$, reflecting dilution of the surface signal. A plausible explanation for the tendency for aircraft $\mathrm{BrO}$ to be lower than surface $\mathrm{BrO}$ is the influence of mixing. Satellite measurements of total column $\mathrm{BrO}$ will be influenced by this mixing process, as well. Below, we quantify the impact of elevated surface $\mathrm{BrO}$ on the total column.

To estimate the tropospheric $\mathrm{BrO}$ column from aircraft measurements, we must first make assumptions about mixing ratios between the surface and the lowest altitude sampled by the aircraft. We only take profiles with aircraft minimum altitudes less than $500 \mathrm{~m}$. Then, we assume that the $\mathrm{BrO}$ mixing ratio in the lowest bin (surface to $500 \mathrm{~m}$ ) is the median $\mathrm{BrO}$ mixing ratio between the lowest aircraft altitude and $500 \mathrm{~m}$. When the aircraft did not sample up to the tropopause, we made assumptions about mixing ratios between the highest aircraft altitude and the tropopause. Here, we use the upper part of the DC- 8 composite profile to fill empty upper bins. However, the DC- 8 composite profile only goes up to $7.5 \mathrm{~km}$, the highest altitude where $\mathrm{BrO}$ is sampled by the aircraft. We assume that the $\mathrm{BrO}$ mixing ratio between $7.5 \mathrm{~km}$ and the tropopause is zero. Aircraft data suggest that $\mathrm{BrO}$ mixing ratios at these altitudes are very small for the sampled air masses (see Fig. 2). It is possible that stratospheric to tropospheric transport of air could supply $\mathrm{BrO}$ to the upper troposphere, particularly along the western flank of Arctic low pressure systems (i.e. after low altitude tropopause systems pass over a region) (Salawitch et al., 2010). This idea is speculative and is not considered below. Finally, layer column $\mathrm{BrO}$ amounts ( $\mathrm{BrO}$ column amounts for vertical bins) are estimated using pressures and temperatures from aircraft measurements and integrated from the surface to the tropopause, to provide a tropospheric column $\mathrm{BrO}$ abundance. We use the tropopause height from the Modern Era RetrospectiveAnalysis for Research and Application (MERRA) data set (see Sect. 2.5).

Tables $1,2 \mathrm{a}$ and $\mathrm{b}$ provide information related to the aircraft $\mathrm{BrO}$ profiles including the bottom and top altitudes of the aircraft in-situ profiles (Alt ${ }_{B}$ and Alt $T_{T}$, respectively), the MERRA tropopause height $\left(\mathrm{H}_{\mathrm{TRP}}\right)$, and the in-situ tropospheric $\mathrm{BrO}$ column (Col.IN-SITU) obtained by integrating the aircraft profiles. Tables $3,4 \mathrm{a}$ and $\mathrm{b}$ provide solar zenith angle (SZA), OMI reflectivity at $331 \mathrm{~nm}\left(R_{331} \mathrm{~nm}\right)$, the difference between terrain and OMI cloud pressure $\left(\Delta P_{\mathrm{c}}\right.$, 
Table 2. Similar to Table 1 but for NOAA WP-3D profiles of BrO, measured on (a) 12 to 15 April 2008, (b) 18 to 21 April 2008.

\begin{tabular}{rrrrrrrrrr}
\hline No. & Day & UTC & $\begin{array}{r}\text { Lat. } \\
\left.{ }^{\circ}\right]\end{array}$ & $\begin{array}{r}\text { Lon. } \\
\left.{ }^{\circ}\right]\end{array}$ & $\begin{array}{r}\text { Alt }_{\mathrm{B}} \\
{[\mathrm{m}]}\end{array}$ & $\begin{array}{r}\mathrm{Alt}_{\mathrm{T}} \\
{[\mathrm{km}]}\end{array}$ & $\begin{array}{r}H_{\mathrm{TRP}} \\
{[\mathrm{km}]}\end{array}$ & $\begin{array}{r}\text { Col. } \\
\text { IN-SITU }\end{array}$ & $\begin{array}{c}\text { Col. } \\
\text { ADDED }\end{array}$ \\
\hline (a) & & & & & & & & & \\
\hline 1 & 12 & $21: 14$ & 65.8 & -148.1 & 289 & 4.6 & 7.4 & 2.55 & $6.5 \%$ \\
2 & 12 & $23: 06$ & 70.6 & -152.7 & 261 & 5.2 & 7.3 & 1.31 & $8.0 \%$ \\
3 & 12 & $23: 39$ & 72.6 & -153.3 & 107 & 4.1 & 7.2 & 1.96 & $37.7 \%$ \\
4 & 12 & $24: 00$ & 74.0 & -153.3 & 77 & 3.3 & 7.0 & 1.27 & $43.8 \%$ \\
5 & 12 & $24: 27$ & 75.1 & -151.2 & 80 & 5.0 & 7.2 & 3.34 & $3.1 \%$ \\
6 & 12 & $24: 54$ & 75.1 & -144.5 & 104 & 5.0 & 6.7 & 0.15 & $67.7 \%$ \\
7 & 12 & $26: 09$ & 74.0 & -139.7 & 99 & 3.4 & 6.5 & 1.41 & $39.4 \%$ \\
8 & 15 & $19: 17$ & 64.8 & -149.5 & 166 & 3.5 & 8.2 & 0.62 & $62.9 \%$ \\
9 & 15 & $22: 24$ & 66.4 & -165.0 & 135 & 4.6 & 5.9 & 0.73 & $22.6 \%$ \\
10 & 15 & $22: 48$ & 67.8 & -165.0 & 135 & 4.3 & 5.9 & 0.81 & $28.5 \%$ \\
11 & 15 & $23: 12$ & 69.1 & -165.1 & 77 & 3.2 & 6.1 & 1.71 & $32.5 \%$ \\
12 & 15 & $24: 30$ & 71.9 & -161.7 & 93 & 6.6 & 6.7 & 0.10 & $2.9 \%$ \\
13 & 15 & $25: 00$ & 71.7 & -161.8 & 100 & 6.5 & 6.6 & 0.07 & $17.9 \%$ \\
14 & 15 & $25: 45$ & 69.6 & -157.2 & 207 & 4.9 & 6.3 & 1.60 & $15.2 \%$ \\
15 & 15 & $26: 50$ & 65.4 & -148.6 & 203 & 5.3 & 7.3 & 1.05 & $10.0 \%$ \\
\hline (b) & & & & & & & & & \\
\hline 16 & 18 & $22: 39$ & 72.5 & -141.9 & 92 & 7.1 & 8.5 & 4.36 & $-0.0 \%$ \\
17 & 18 & $23: 24$ & 73.0 & -137.7 & 107 & 6.8 & 8.4 & 0.85 & $0.4 \%$ \\
18 & 18 & $24: 51$ & 70.9 & -144.2 & 146 & 5.2 & 9.6 & 1.92 & $5.5 \%$ \\
19 & 19 & $22: 18$ & 65.5 & -148.5 & 219 & 4.8 & 11.7 & 4.49 & $13.8 \%$ \\
20 & 19 & $24: 06$ & 71.5 & -156.5 & 188 & 4.7 & 8.7 & 2.44 & $6.8 \%$ \\
21 & 19 & $26: 51$ & 74.0 & -160.0 & 151 & 3.8 & 6.6 & 1.79 & $22.0 \%$ \\
22 & 19 & $27: 39$ & 72.6 & -153.8 & 151 & 7.4 & 8.1 & 2.12 & $0.0 \%$ \\
23 & 19 & $29: 04$ & 66.7 & -149.1 & 304 & 5.4 & 11.3 & 2.29 & $4.6 \%$ \\
24 & 21 & $18: 31$ & 66.0 & -145.6 & 287 & 6.1 & 11.0 & 4.38 & $0.3 \%$ \\
25 & 21 & $21: 21$ & 72.7 & -127.3 & 316 & 6.3 & 8.4 & 1.43 & $6.6 \%$ \\
26 & 21 & $23: 27$ & 69.6 & -136.7 & 159 & 4.6 & 10.6 & 0.96 & $17.3 \%$ \\
27 & 21 & $24: 10$ & 69.5 & -136.7 & 164 & 4.7 & 10.5 & 1.31 & $12.7 \%$ \\
28 & 21 & $25: 21$ & 69.3 & -137.6 & 162 & 5.9 & 10.3 & 2.97 & $17.3 \%$ \\
29 & 21 & $26: 24$ & 66.1 & -146.0 & 222 & 5.4 & 11.0 & 1.58 & $6.6 \%$ \\
\hline & & & & & & & & & \\
\hline
\end{tabular}

explained in Sect. 2.4), the satellite-derived tropospheric columns from OMI (Col.oMI) and GOME-2 (Col.GOME-2) corresponding to the in-situ aircraft $\mathrm{BrO}$ profiles, and the ratios of satellite-derived tropospheric $\mathrm{BrO}$ columns to the in-situ BrO columns (RatioomI and RatiogOME-2) (see Sects. 2.2 and 3.2 for a description of the satellite data and related parameters in these tables).

The lowest altitudes sampled by the DC- 8 and WP-3D during their descents over BrO-enhanced regions were 75 and $77 \mathrm{~m}$, respectively. In our analysis we use the composite DC8 or WP-3D profile to extrapolate between the lowest sampled altitude and the surface, for each formulation of in-situ column BrO shown in Tables 1, 2a, and b. At times, surface $\mathrm{BrO}$ can reach mixing ratios as high as $40 \mathrm{pptv}$ (Liao et al., 2011a). We have assessed the impact of elevated surface $\mathrm{BrO}$ on our analysis of aircraft, satellite, and modeled stratospheric columns by conducting a probability distribu- tion function for daytime surface BrO, observed at Barrow, Alaska. Two thirds of the time, surface $\mathrm{BrO}$ is below 8 pptv (Fig. S2). A uniform distribution of $8 \mathrm{pptv}$ of $\mathrm{BrO}$ between the surface and $75 \mathrm{~m}$ altitude would contribute $0.18 \times 10^{13}$ $\mathrm{cm}^{-2}$ to the column, an amount much smaller than the in situ and satellite-based columns discussed throughout the paper (see caption, Figure S2). Levels of BrO reaching 40 pptv below the aircraft would contribute $1 \times 10^{13} \mathrm{~cm}^{-2}$ to the column if the $\mathrm{BrO}$ where present, at this amount, uniformly between the surface and $75 \mathrm{~m}$ altitude. The PDF analysis shows that while surface BrO did reach 40 ppt in spring 2009, such occurrences were rare. While layers of highly elevated $\mathrm{BrO}$ below the aircraft could on occasion compromise our comparisons, our overall conclusions are robust because surface measurements indicate only on rare occaison are $\mathrm{BrO}$ enhancements large enough to significantly perturb the column. 
Table 3. Satellite-derived information corresponding to DC-8 BrO profile locations shown in Fig. 1. Units and abbreviations are as used in Tables 1, 2a and b. "Ratio OMI" means ratio of the OMI-derived tropospheric column to the in-situ column. "Ratio $\mathrm{GOME}-2$ " is the same but for GOME-2.

\begin{tabular}{rrrrrrrrr}
\hline No. & Day & $\begin{array}{r}\text { SZA } \\
{\left[{ }^{\circ}\right]}\end{array}$ & $R_{331 \mathrm{~nm}}$ & $\begin{array}{r}\Delta P_{\mathrm{c}} \\
{[\mathrm{hPa}]}\end{array}$ & $\begin{array}{r}\text { Col. } \\
\text { OMI }\end{array}$ & $\begin{array}{r}\text { Col. } \\
\text { GOME- }\end{array}$ & $\begin{array}{r}\text { Ratio } \\
\text { OMI }\end{array}$ & $\begin{array}{r}\text { Ratio } \\
\text { GOME-2 }\end{array}$ \\
\hline 1 & 16 & 60 & 0.80 & 19.9 & 0.98 & 1.08 & 0.23 & 0.25 \\
2 & 16 & 61 & 0.88 & 46.7 & 4.12 & 3.91 & 1.52 & 1.44 \\
3 & 16 & 63 & 0.91 & 41.2 & 2.99 & 3.67 & 0.78 & 0.96 \\
4 & 16 & 61 & 0.89 & 44.2 & 2.35 & 2.78 & 1.17 & 1.39 \\
5 & 16 & 56 & 0.85 & 23.4 & 2.15 & 2.33 & 0.74 & 0.80 \\
6 & 16 & 55 & 0.83 & 49.3 & 1.97 & 2.26 & 0.72 & 0.82 \\
7 & 17 & 59 & 0.85 & 15.8 & 2.70 & 1.80 & 1.03 & 0.79 \\
8 & 17 & 60 & 0.86 & 21.3 & 2.47 & 2.65 & 1.17 & 1.26 \\
9 & 17 & 67 & 0.88 & 31.1 & 3.10 & 2.31 & 0.81 & 0.60 \\
10 & 17 & 70 & 0.90 & 46.3 & 2.21 & 1.54 & 0.65 & 0.45 \\
11 & 17 & 74 & 0.87 & 82.7 & 3.11 & 2.81 & 1.05 & 0.95 \\
12 & 17 & 77 & 0.87 & 146.9 & 4.69 & 5.08 & 1.08 & 1.17 \\
13 & 17 & 74 & 0.90 & 39.6 & 2.85 & 2.16 & 0.55 & 0.42 \\
14 & 17 & 75 & 0.90 & 32.9 & 2.81 & 2.05 & 1.15 & 0.84 \\
15 & 17 & 78 & 0.86 & 33.5 & 2.48 & 2.82 & 1.26 & 1.43 \\
16 & 17 & 80 & 0.85 & 38.6 & 2.32 & 2.17 & 1.25 & 1.16 \\
\hline
\end{tabular}

In addition to $\mathrm{BrO}$, other aircraft trace gas measurements are useful for inferring halogen chemistry and air mass characteristics. For example, $\mathrm{Br}_{2}$ was measured by CIMS instruments from both aircraft. Laboratory studies revealed that the $\mathrm{Br}_{2}$ signals include contributions from $\mathrm{HOBr}$ that reacted on inlet surfaces. Therefore, $\mathrm{Br}_{2}$ represents the lower limit of $\mathrm{HOBr}+\mathrm{Br}_{2}$ (Neuman et al., 2010). Henceforth, we refer to this measurement as "active bromine". Soluble bromide was also measured from the DC- 8 using mist chamber/ion chromatography. Soluble bromide may include inorganic bromine compounds such as $\mathrm{HBr}, \mathrm{HOBr}$, particulate bromine, and possibly $\mathrm{BrO}$ and $\mathrm{Br}_{2}$ (Ridley et al., 2003; Dibb et al., 2010; Neuman et al., 2010; Liao et al., 2011b). Measurements of $\mathrm{O}_{3}$ mixing ratios by chemiluminescence were made from both aircraft. CO was measured using tunable diode laser absorption spectroscopy on the DC-8 and UV fluorescence on the WP-3D (Jacob et al., 2010; Brock et al., 2011).

\subsection{Total BrO slant column density from OMI and GOME-2}

OMI is a nadir-viewing ultraviolet and visible (UV/Vis) sensor (Levelt et al., 2006) aboard the NASA Aura satellite that is in a sun-synchronous orbit with an overpass of 01:38 p.m. local time. The spectral resolution in the OMI UV-2 channel used to retrieve $\mathrm{BrO}$ columns is approximately $0.5 \mathrm{~nm}$. The OMI swath width is about $2600 \mathrm{~km}$. The pixel size of OMI UV-2 channel is approximately $13 \times 24 \mathrm{~km}^{2}$ at the swath center and significantly larger at the swath edges. With its wide swath, OMI provides multiple daily observations at high latitudes in spring and daily global coverage at low and middle latitudes. An obstruction outside the instrument that produces radiance errors (known as the "row anomaly") reduced the swath coverage mainly after May 2008; it does not significantly affect the observations shown here (Claas et al., 2010).

OMI BrO SCDs are retrieved by directly fitting backscattered UV radiances to absorption cross-sections of $\mathrm{BrO}$ (the target gas), $\mathrm{NO}_{2}, \mathrm{HCHO}$, and $\mathrm{SO}_{2}$ as well as inelastic rotational-Raman scattering (also known as the Ring effect) using a non-linear least-squares approach (Chance, 1998). The spectral fitting window for the OMI algorithm is 319 to $347.5 \mathrm{~nm}$. BrO cross sections from Wilmouth et al. (1999) are used. The total fitting uncertainty of OMI BrO total column typically ranges from 15 to $51 \%$ (Salawitch et al., 2010; Kurosu and Chance, 2011).

GOME-2 is a 4 channel UV/Vis nadir viewing instrument operating on Metop-A since January 2007 (Callies et al., 2000). It has a local equator crossing time of 9:30 am in the descending node, a swath width of $1920 \mathrm{~km}$, and a spatial resolution of $40 \times 80 \mathrm{~km}^{2}$. For the BrO SCD retrieval used here (Begoin et al., 2010), measurements in the window 336 to $347 \mathrm{~nm}$ are used, where GOME-2 has a spectral resolution of about $0.3 \mathrm{~nm}$. SCDs of $\mathrm{BrO}$ are retrieved using the standard DOAS approach. Absorption due to $\mathrm{BrO}$ (Wahner et al., 1988), $\mathrm{O}_{3}, \mathrm{NO}_{2}$, and the effects of rotational-Raman scattering are included. The uncertainty of the GOME- $2 \mathrm{BrO}$ total SCDs is 10 to $30 \%$ depending on solar zenith angle (SZA) and surface albedo. The uncertainty has both random and systematic contributions from spectral interferences and the cross-sections. As a result of throughput loss of the UV 
Table 4. Similar to Table 3 but for NOAA WP-3D profiles of BrO, measured on (a) 12 to 15 April 2008, (b) 18 to 21 April 2008.

\begin{tabular}{rrrrrrrrr}
\hline No. & Day & $\begin{array}{c}\text { SZA } \\
{\left[^{\circ}\right]}\end{array}$ & $R_{331 \mathrm{~nm}}$ & $\begin{array}{r}\Delta P_{\mathrm{c}} \\
{[\mathrm{hPa}]}\end{array}$ & $\begin{array}{r}\text { Col. } \\
\text { OMI }\end{array}$ & $\begin{array}{r}\text { Col. } \\
\text { GOME-2 }\end{array}$ & $\begin{array}{r}\text { Ratio } \\
\text { OMI }\end{array}$ & $\begin{array}{r}\text { Ratio } \\
\text { GOME-2 }\end{array}$ \\
\hline (a) & & & & & & & & \\
\hline 1 & 12 & 57 & 0.44 & 11.9 & -0.46 & - & -0.18 & - \\
2 & 12 & 62 & 0.89 & 85.9 & 1.59 & - & 1.22 & - \\
3 & 12 & 65 & 0.89 & 80.4 & 1.24 & 1.43 & 0.63 & 0.73 \\
4 & 12 & 67 & 0.90 & 89.5 & 2.00 & 2.31 & 1.58 & 1.82 \\
5 & 12 & 69 & 0.90 & 80.7 & 1.58 & 1.95 & 0.47 & 0.58 \\
6 & 12 & 72 & 0.89 & 70.7 & 1.04 & 2.00 & 6.70 & 12.94 \\
7 & 12 & 77 & 0.90 & 76.5 & 1.23 & 1.21 & 0.87 & 0.86 \\
8 & 15 & 62 & 0.45 & 155.9 & -1.39 & -0.42 & -2.23 & -0.67 \\
9 & 15 & 57 & 0.85 & 79.7 & 2.09 & 2.88 & 2.85 & 3.93 \\
10 & 15 & 58 & 0.86 & 92.9 & 1.63 & 2.20 & 2.01 & 2.71 \\
11 & 15 & 59 & 0.86 & 92.7 & 2.19 & 2.45 & 1.28 & 1.44 \\
12 & 15 & 64 & 0.90 & 104.3 & 2.07 & 3.56 & 19.74 & 34.07 \\
13 & 15 & 65 & 0.91 & 106.1 & 2.33 & 3.21 & 32.63 & 44.95 \\
14 & 15 & 67 & 0.94 & 106.7 & 1.97 & 2.22 & 1.24 & 1.39 \\
15 & 15 & 74 & 0.46 & 77.8 & 0.28 & -0.58 & 0.27 & -0.55 \\
\hline (b) & & & & & & & & \\
\hline 16 & 18 & 62 & - & - & 4.08 & 2.71 & 0.94 & 0.62 \\
17 & 18 & 65 & - & - & 4.20 & 2.81 & 4.97 & 3.32 \\
18 & 18 & 67 & - & - & 3.76 & 2.14 & 1.96 & 1.12 \\
19 & 19 & 54 & 0.61 & 279.7 & 0.91 & 0.33 & 0.20 & 0.07 \\
20 & 19 & 62 & 0.78 & 176.6 & 1.97 & 2.55 & 0.81 & 1.04 \\
21 & 19 & 72 & 0.83 & 142.0 & 4.23 & 6.00 & 2.37 & 3.36 \\
22 & 19 & 77 & 0.79 & 179.7 & 1.22 & 1.80 & 0.58 & 0.85 \\
23 & 19 & 86 & 0.72 & 263.6 & 0.78 & 0.95 & 0.34 & 0.42 \\
24 & 21 & 63 & 0.47 & 266.0 & 0.12 & 0.25 & 0.03 & 0.06 \\
25 & 21 & 61 & 0.83 & 110.5 & 3.03 & 3.54 & 2.13 & 2.48 \\
26 & 21 & 62 & 0.80 & 198.1 & 3.14 & 3.29 & 3.27 & 3.43 \\
27 & 21 & 64 & 0.80 & 205.6 & 3.02 & 3.45 & 2.32 & 2.64 \\
28 & 21 & 69 & 0.79 & 193.5 & 2.40 & 2.87 & 0.81 & 0.97 \\
29 & 21 & 71 & 0.47 & 260.5 & 0.12 & 0.29 & 0.07 & 0.18 \\
\hline & & & & & & & & \\
& & & & & & & & \\
\end{tabular}

channels, random errors have increased since launch. However, this effect is not significant during the time period studied here (Dikty et al., 2011).

All of the analyses conducted in this study are based on the assumption that the magnitude of satellite-derived slant column is correct. A detailed analysis of the errors involved in deriving satellite-derived slant columns of $\mathrm{BrO}$ is beyond the scope of this paper. There are potentially large uncertainties associated with the derivation of both slant and vertical absolute column BrO related to the choice of spectral fitting windows and various DOAS parameters (e.g., polynomial order, orthogonalizations) used in retrievals as well as assumed $\mathrm{BrO}$ vertical profiles (G. Mount, private communication, 2011; DLR, 2009).

For all analyses conducted in this study, we use level 2 (time-ordered) satellite data. Level 2 data provide the best temporal match between satellite observations and aircraft in-situ and ground-based observations.

\subsection{Stratospheric BrO column}

A model simulation of stratospheric bromine species is used to estimate the spatial structure of the stratospheric $\mathrm{BrO}$ column. Our approach is similar to that described by Salawitch et al. (2010), but differs in that they showed results for a fixed local solar time of 01:30 p.m. whereas here we calculate $\mathrm{BrO}$ along each OMI or GOME-2 orbit, which spans a range of local solar times near the pole. A photochemical steady state (PSS) model is constrained to profiles of temperature, $\mathrm{O}_{3}$, $\mathrm{NO}_{\mathrm{y}}, \mathrm{Cl}_{\mathrm{y}}, \mathrm{H}_{2} \mathrm{O}, \mathrm{CH}_{4}$, sulfate aerosol surface area, etc. output from a run of Whole Atmosphere Community Climate Model (WACCM) (Garcia et al., 2007) conducted using meteorological fields for spring 2008. Salawitch et al. (2010) provide a description of this WACCM run, which was conducted to support the Stratosphere-Troposphere Analyses of Regional Transport 2008 campaign. 
We specify the vertical distribution of $\mathrm{Br}_{\mathrm{y}}$ (the total bromine content of all inorganic bromine species) input to the PSS model, based on a relation between $\mathrm{Br}_{\mathrm{y}}$ and CFC12. Profiles of CFC-12 are from the NASA Global Modeling and Assimilation Office (GMAO) Goddard Earth Observing System Data Assimilation System Version 5 (GEOS-5) (Rienecker et al., 2007) assimilation for spring 2008. Salawitch et al. (2010) evaluated the sensitivity of stratospheric partial column $\mathrm{BrO}$ to the amount of stratospheric bromine supplied by VSL bromocarbons, termed VSL $\mathrm{Br}_{\mathrm{y}}$. The value of VSL $\mathrm{Br}_{\mathrm{y}}$ is quite uncertain: Table 1-9 of (WMO, 2011) gives a range of 1 to $8 \mathrm{ppt}$ for this quantity.

The PSS model is used to find $\mathrm{BrO}$, at the local solar time of each OMI or GOME-2 orbit, assuming production and loss of all species are in balance over a $24 \mathrm{~h}$ period of time for a stationary air parcel. Then, $\mathrm{BrO}$ abundance is integrated from the pressure of the tropopause (WMO definition of the thermal tropopause, based on GEOS-5 temperature) to $0.01 \mathrm{hPa}$, yielding stratospheric column BrO. The diurnal variation of the stratospheric column $\mathrm{BrO}$ must be considered in estimating tropospheric BrO column, especially for the high SZAs of the level 2 data examined below. Further details of the PSS model are provided in Sect. 6.3.2 of SPARC CCMVal (2010), and references therein.

As noted above, the $\mathrm{Br}_{\mathrm{y}}$ versus $\mathrm{CFC}-12$ relation used here consists of a baseline value of $\mathrm{Br}_{\mathrm{y}}$ plus $7 \mathrm{ppt}$ (representing stratospheric injection of bromine in the form of product gases of VSL bromocarbons). Baseline $\mathrm{Br}_{\mathrm{y}}$ is set to zero at the tropopause and represents, above the tropopause, supply of bromine from the decomposition of methyl bromide $\left(\mathrm{CH}_{3} \mathrm{Br}\right)$, halons, as well as dibromethane $\left(\mathrm{CH}_{2} \mathrm{Br}_{2}\right)$. Other groups place $\mathrm{CH}_{2} \mathrm{Br}_{2}$ into the definition of $\mathrm{VSL} \mathrm{Br}_{\mathrm{y}}$. We consider $\mathrm{CH}_{2} \mathrm{Br}_{2}$ to be part of baseline $\mathrm{Br}_{\mathrm{y}}$, however, because this compound is observed above the tropical tropopause (e.g. Wamsley et al., 1998). The total stratospheric $\mathrm{Br}_{\mathrm{y}}$ burden of $26 \mathrm{ppt}$ used here is at the upper end of the present range of uncertainty (e.g. WMO, 2011). This formulation (7 ppt for $\mathrm{VSL} \mathrm{Br}_{\mathrm{y}}$ plus baseline that includes $\mathrm{CH}_{2} \mathrm{Br}_{2}$ ) was chosen because it results in best agreement between OMI total column $\mathrm{BrO}$ and the sum of stratospheric (modeled) and tropospheric (measured) partial column BrO. A wide range of values for $\mathrm{VSL} \mathrm{Br}_{\mathrm{y}}$ yields "reasonable agreement" between these two terms when all uncertainties are considered (Fig. 6, Auxiliary Material, Salawitch et al., 2010). Despite the considerable uncertainty in stratospheric $\mathrm{Br}_{\mathrm{y}}$ and the impact of this parameter on tropospheric BrO column inferred from satellite observations of total column $\mathrm{BrO}$, our approach of using a value for stratospheric $\mathrm{Br}_{\mathrm{y}}$ near the upper end is supported by the generally close quantitative agreement between inferences of tropospheric $\mathrm{BrO}$ column from the satellites and the in-situ data, described below. As noted previously, the fields of stratospheric $\mathrm{BrO}$ used here are approximately $27 \%$ larger than those reported by Theys et al. (2011) (with percentage differences that vary considerably with respect to location as shown in Fig. S1).

\subsection{Cloud parameters}

Optically thick clouds shield the underlying atmosphere from satellite sensors. The OMI rotational Raman (RR) cloud product (Vasilkov et al., 2008) is used to infer information about the shielding effects of clouds over snow and ice (Vasilkov et al., 2010). This product provides an estimate of the scene (combined cloud and surface) pressure over snow and ice surfaces. The Near-real-time SSM/I EASE-grid daily global Ice and snow concentration and Snow Extent (NISE) data set (Nolin et al., 1998) is used to identify snow and ice-covered pixels. When the difference between scene and terrain pressure $\left(\Delta P_{\mathrm{c}}\right)$ exceeds $250 \mathrm{hPa}$ we infer that clouds have led to significant shielding of tropospheric $\mathrm{BrO}$ from the satellite sensor (Vasilkov et al., 2010), as discussed below.

We use level 3 (gridded) cloud optical thickness and cloudtop pressure retrievals from the MODerate-resolution Imaging Spectroradiometer (MODIS) (Platnick et al., 2003) on the NASA Aqua satellite as a secondary check on our detection of shielding clouds. Analysis of cloud effects on the satellitederived tropospheric BrO columns is presented in Sect. 3.2.

\subsection{Meteorological data sets}

Tropopause heights are inferred along the flight tracks using tropopause pressure and geopotential height profiles from MERRA, a reanalysis based on GEOS-5 system (Rienecker et al., 2007) provided by NASA Global Modeling and Assimilation Office (GMAO). These tropopause heights are used to integrate the aircraft BrO profiles and are given in Tables 1, $2 \mathrm{a}$ and $\mathrm{b}$. MERRA also provides meteorological parameters including sea level pressure, wind speed, and planetary boundary layer height. These meteorological data are used to infer relationships between $\mathrm{BrO}$ enhancements and the meteorological conditions. MERRA parameters are provided at $0.5^{\circ}$ latitude $\times 0.667^{\circ}$ longitude resolution. All parameters except geopotential height profiles are provided hourly; geopotential height is given every $6 \mathrm{~h}$.

\section{Derivation of tropospheric BrO vertical column density}

\subsection{Residual method to obtain tropospheric BrO vertical column density}

Tropospheric column BrO can be obtained from satellite total column $\mathrm{BrO}$ retrievals using the residual method (e.g. Theys et al., 2011, and references therein). Here, as in Theys et al. (2011), we calculate tropospheric BrO vertical column densities $\left(\mathrm{VCD}_{\mathrm{Trop}}\right)$ for each OMI or GOME-2 pixel using the derived $\mathrm{BrO}$ total slant column $\left(\mathrm{SCD}_{\mathrm{Total}}\right)$, an estimate of stratospheric BrO vertical column ( $\left.\mathrm{VCD}_{\text {Strat }}\right)$, stratospheric air mass factors $\left(\mathrm{AMF}_{\mathrm{Strat}}\right)$, and an estimate of the 
tropospheric air mass factor $\left(\mathrm{AMF}_{\mathrm{Trop}}\right)$ as follows:

$$
\begin{aligned}
& \mathrm{VCD}_{\text {Trop }}=\frac{\mathrm{SCD}_{\text {Trop }}}{\mathrm{AMF}_{\text {Trop }}}=\frac{\left(\mathrm{SCD}_{\text {Total }}-\mathrm{SCD}_{\text {Strat }}\right)}{\mathrm{AMF}_{\text {Trop }}} \\
& =\frac{\left(\mathrm{SCD}_{\text {Total }}-\mathrm{VCD}_{\text {Strat }} \cdot \mathrm{AMF}_{\text {Strat }}\right)}{\mathrm{AMF}_{\text {Trop }}} .
\end{aligned}
$$

The SCD of a given absorber seen by a satellite sensor is defined as the amount of the absorber along an average light path taken by photons as they travel from the sun, through the atmosphere, and back to the sensor. The SCD is affected by scattering and absorption within the atmosphere as well as reflection off the surface and clouds.

For a given altitude range (denoted by a subscript $z$ ), The air mass factor $\left(\mathrm{AMF}_{z}\right)$ is used to convert $\mathrm{SCD}_{z}$ to $\mathrm{VCD}_{z}$ as follows:

$\mathrm{AMF}_{z}=\mathrm{SCD}_{z} / \mathrm{VCD}_{z}$.

The sensitivity of UV radiance measurements to the $\mathrm{BrO}$ layer amounts varies with altitude. This variation depends on viewing geometry (mainly solar zenith angle, SZA, and view zenith angle, VZA), surface albedo, cloud effects, and the vertical $\mathrm{BrO}$ profile. We must account for this varying sensitivity in the AMF. Using the optically thin absorber assumption, the $\mathrm{AMF}_{z}$ can be formulated as

$\mathrm{AMF}_{z}=\mathrm{SCD}_{z} / \mathrm{VCD}_{z}=\frac{\int W(z) N(z) d z}{\int N(z) d z}$,

(Palmer et al., 2001; Theys et al., 2011), where $z$ is altitude, $N(z)$ is the number density profile of the absorber, and $W(z)$ is the weighting function profile that represents all the parameters influencing the AMF except the vertical profile of the absorber.

Here, we use estimates of $\mathrm{AMF}_{\text {Strat }}$ provided in the OMI and GOME-2 total $\mathrm{BrO}$ column products. $\mathrm{AMF}_{\text {Strat }}$ for GOME-2 is computed using the SCIATRAN radiative transfer model (Rozanov et al., 2005). The OMI algorithm uses a different approach to calculate $\mathrm{AMF}_{\text {Strat }}$; $\mathrm{BrO}$ VCDs are obtained by applying wavelength- and albedo-dependent AMFs to the $\mathrm{BrO}$ absorption cross sections prior to fitting. It is assumed that all $\mathrm{BrO}$ resides in the stratosphere in this procedure. An effective AMF is then defined as the ratio of the SCD (derived independently as described in Sect. 2.2) to this VCD. We assume that $\mathrm{AMF}_{\text {Strat }}$ is represented by this effective air mass factor.

We compute the tropospheric $\mathrm{AMF}_{\text {Trop }}$ at $344.6 \mathrm{~nm}$ using the LInearized Discrete Ordinate Radiative Transfer (LIDORT) model (Spurr et al., 2001). We use a clear scene assumption in the AMF calculation. The DC-8 composite profile shown in Fig. 2a is taken as the default tropospheric $\mathrm{BrO}$ profile in the $\mathrm{AMF}_{\text {Trop }}$ calculation. However, we use individual aircraft profiles of $\mathrm{BrO}$, from both the $\mathrm{DC}$ 8 and WP-3D, to calculate $\mathrm{AMF}_{\text {Trop }}$ for point-to-point comparisons between aircraft in-situ and satellite-derived tropospheric columns.

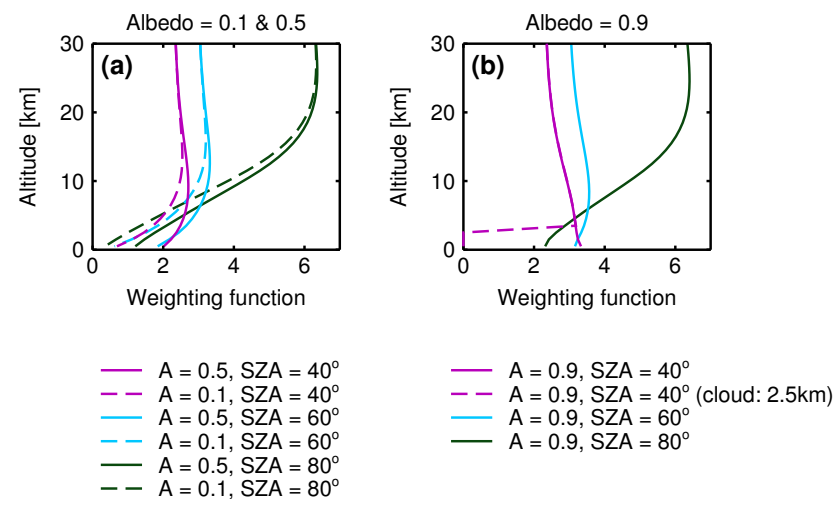

Fig. 3. BrO weighting functions at $344.6 \mathrm{~nm}$ for various solar zenith angles (SZA) and surface albedos (A), for (a) clear sky conditions and (b) clear and cloudy sky conditions, where the cloudy case is for an optically thick cloud (cloud extinction coefficient $=300$ ) at $2.5 \mathrm{~km}$ altitude.

We have generated a look-up table of $\mathrm{AMF}_{\mathrm{Trop}}$ for various representative surface albedos and viewing geometries. A $5^{\circ}$ interval for SZA and a $2.5^{\circ}$ interval for VZA are used. Because the weighting functions are highly dependent on surface albedo, we use step-widths of 0.1 in the range $[0,1]$ for surface albedo.

The calculation of $\mathrm{AMF}_{\text {Trop }}$ uses the derived OMI reflectivity at $331 \mathrm{~nm}$ for each pixel, from the OMI Total Ozone Mapping Spectrometer (TOMS) total $\mathrm{O}_{3}$ product, as a proxy for surface albedo. We thus avoid using a surface albedo climatology, which can lead to AMF errors when the climatology differs from the actual surface albedo. Such errors can occur when the snow or sea ice distribution differs from the climatological mean, which is of particular concern at high latitudes during spring.

\subsection{Sensitivity of the derived tropospheric column to SZA, surface albedo, and clouds}

Here, we investigate the sensitivity of the satellite-derived tropospheric $\mathrm{BrO}$ retrieval to SZA, surface albedo, and clouds. Theys et al. (2011) analyzed the dependence of the weighting function on surface albedo and clouds for $\mathrm{SZA}=45^{\circ}$. Here, we extend this analysis to a wider SZA range $\left(40^{\circ}-90^{\circ}\right)$ relevant to polar observing conditions; at high latitudes $\left(>60^{\circ} \mathrm{N}\right)$ during the day in the early spring $\mathrm{SZA}$ is $>50^{\circ}$. Figure $3 \mathrm{a}$ shows that when the sun is relatively high in the sky $\left(\mathrm{SZA} \leq \sim 60^{\circ}\right)$, OMI and GOME-2 should have good sensitivity to tropospheric $\mathrm{BrO}$ for surface albedos $>0.5$. Sensitivity is significantly reduced for darker surfaces (e.g. albedo $=0.1$ ). Sensitivity to tropospheric $\mathrm{BrO}$ decreases with increasing SZA; there is significantly lower sensitivity at $80^{\circ}$ even for a surface albedo of 0.5 . Figure $3 \mathrm{~b}$ shows that at high surface albedo (0.9), there is increased sensitivity to $\mathrm{BrO}$ near the surface in addition to good overall tropospheric sensitivity for SZA up to $80^{\circ}$. 

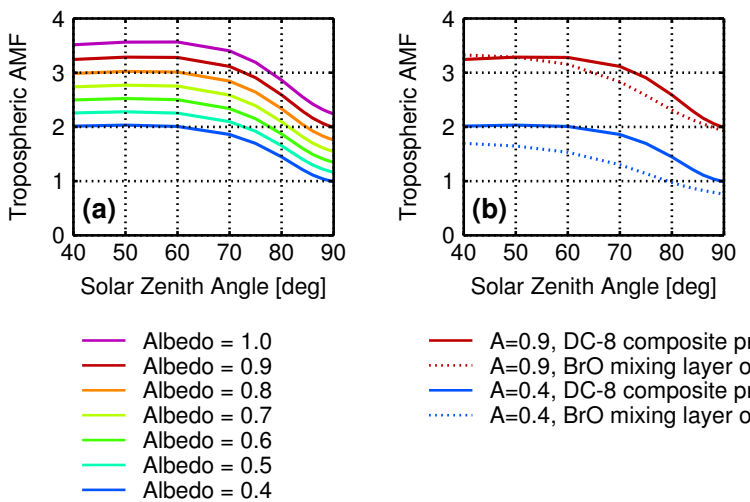
- $A=0.9$, DC- 8 composite profile
…... $A=0.9$, BrO mixing layer of $500 \mathrm{~m}$
— $A=0.4$, DC-8 composite profile $A=0.4, B r O$ mixing layer of $500 m$

Fig. 4. (a) Tropospheric air mass factors (AMFs) at $344.6 \mathrm{~nm}$ computed using the DC- 8 composite $\mathrm{BrO}$ profile for various surface albedos as a function of SZA; (b) similar to (a) but also showing AMFs found assuming all of the $\mathrm{BrO}$ is below $500 \mathrm{~m}$ (dotted lines). A refers again to surface albedo.

The effect of optically thin clouds and aerosols on the sensitivity of OMI and GOME-2 to tropospheric BrO is dependent on surface reflectivity and viewing geometry. Vasilkov et al. (2010) showed that the sensitivity of UV satellite measurements to trace gas absorption near the surface in clear skies with moderately high surface albedo $(70 \%)$ is approximately the same as for substantially cloudy conditions (optical thicknesses up to about 30) over a higher albedo surface (90\%); the cloud shielding effect is much reduced for high albedo surfaces. In addition, enhanced absorption takes place above a cloud of moderate to high optical thickness. According to Vasilkov et al. (2010), the UV cloud shielding effect is generally reduced over bright surfaces as compared to dark surfaces for nadir-viewing satellite sensors. For example, there is good sensitivity to tropospheric absorbers below thin clouds over bright surfaces near the nadir swath positions for SZAs $\leq \sim 67^{\circ}$. On the other hand, their simulation shows that there can be UV cloud shielding at the swath edge at high solar zenith angles, even for a thin cloud $(\tau \sim 0.5)$. The clear scene assumption in the AMF calculation is appropriate over bright surfaces (i.e. snow/ice) when the derived scene pressure is close to the terrain pressure, which indicates that any particles along the line of sight must either be a thin, non-shielding cloud or an aerosol layer (the so-called Arctic haze) common in polar regions. The optical thickness of Arctic haze during ARCTAS was reported to be up to $\sim 0.2$ at $354 \mathrm{~nm}$ (Shinozuka et al., 2011). Based on the calculations of Vasilkov et al. (2010), OMI and GOME-2 should have good sensitivity to surface $\mathrm{BrO}$ in Arctic haze conditions at the near-nadir swath positions, but may have reduced sensitivity at the swath edge. However, as shown by Theys et al. (2011) and in Fig. 3b, optically thick clouds can shield satellite measurements from absorbers including $\mathrm{BrO}$.

Figure 4a shows computed tropospheric air mass factors. As shown for the weighting functions in Fig. 3, tropospheric air mass factors are higher over brighter surfaces owing to increased near-surface sensitivity. However, tropospheric sensitivity begins to be lost as SZA increases; tropospheric sensitivity almost disappears when $\mathrm{SZA}>80^{\circ}$ even for relatively bright surfaces. In this study, we present satellite-derived $\mathrm{BrO}$ tropospheric columns only for SZA $<80^{\circ}$.

The sensitivity of $\mathrm{AMF}_{\text {Trop }}$ to the tropospheric $\mathrm{BrO}$ profile is assessed in Fig. 4b. For a bright surface (albedo $=0.9$ ), no significant difference exists between tropospheric AMFs computed using the DC- 8 composite profile and a profile where all tropospheric $\mathrm{BrO}$ is contained below $500 \mathrm{~m}$ for $\mathrm{SZA} \leq \sim 60^{\circ}$. This is a consequence of good sensitivity at all tropospheric altitudes for bright surfaces and low SZA as shown in Fig. 3. For $60^{\circ}<\mathrm{SZA}<75^{\circ}$, the sensitivity to middle- and upper-tropospheric $\mathrm{BrO}$ is maintained while the near-surface sensitivity drops; this leads to a small sensitivity to the profile shape under these conditions. Profile sensitivity decreases for higher SZAs as the sensitivity to the entire troposphere drops. For a darker surface $($ albedo $=0.4)$, the retrieval has lower sensitivity to $\mathrm{BrO}$ near the surface even when the sun is relatively high $\left(\mathrm{SZA} \sim 40^{\circ}\right)$. In this case, the retrieval of total column $\mathrm{BrO}$ and our inference of the tropospheric column will be sensitive to the shape of the profile of $\mathrm{BrO}$ in the troposphere. If most of the tropospheric column happened to originate from $\mathrm{BrO}$ in the lowest $500 \mathrm{~m}$ of the atmosphere, then our inference of tropospheric column would be biased low over dark surfaces.

We next examine tropospheric column $\mathrm{BrO}$ estimated from OMI in the context of the different sensitivities discussed above. Figure 5 shows OMI total, the model stratospheric, and the derived tropospheric $\mathrm{BrO}$ columns for OMI orbit 20050 on 22 April 2008 along with several parameters that impact the sensitivity of the radiance observation to the tropospheric BrO column. These parameters include $331 \mathrm{~nm}$ reflectivity (a proxy for surface albedo), $\Delta P_{\mathrm{c}}$, and SZA.

OMI total column BrO in Fig. 5a, within the region of the Barents Sea (black box), shows significant gradient. The region of high total $\mathrm{BrO}$ towards the upper left hand corner of the black box is associated with enhanced stratospheric burden (Fig. 5b, orange). Another region of large total $\mathrm{BrO}$ (lower portion of black box) is associated, by our analysis, with an enhanced tropospheric burden (Fig. 5c, red). This region of enhanced tropospheric $\mathrm{BrO}$ occurs over a bright portion of the Barents Sea (Fig. 5d, crimson, indicating snow or ice). Nearly zero tropospheric BrO column amounts are obtained over low surface albedo areas (OMI reflectivity $<0.5)$ of the Barents Sea (Fig. 5d, blue). Here, the retrieved total columns are generally less than retrieved columns over adjacent areas with higher reflectivity, leading to low tropospheric column BrO over parts of the Barent Sea. However, satellite-derived tropospheric $\mathrm{BrO}$ may not be reliable when the surface albedo is low. While it is possible tropospheric column $\mathrm{BrO}$ was truly low on 22 April over this region of the Barents Sea due to the lack of snow or ice leads that may be needed for bromine activation, it is also possible that our 

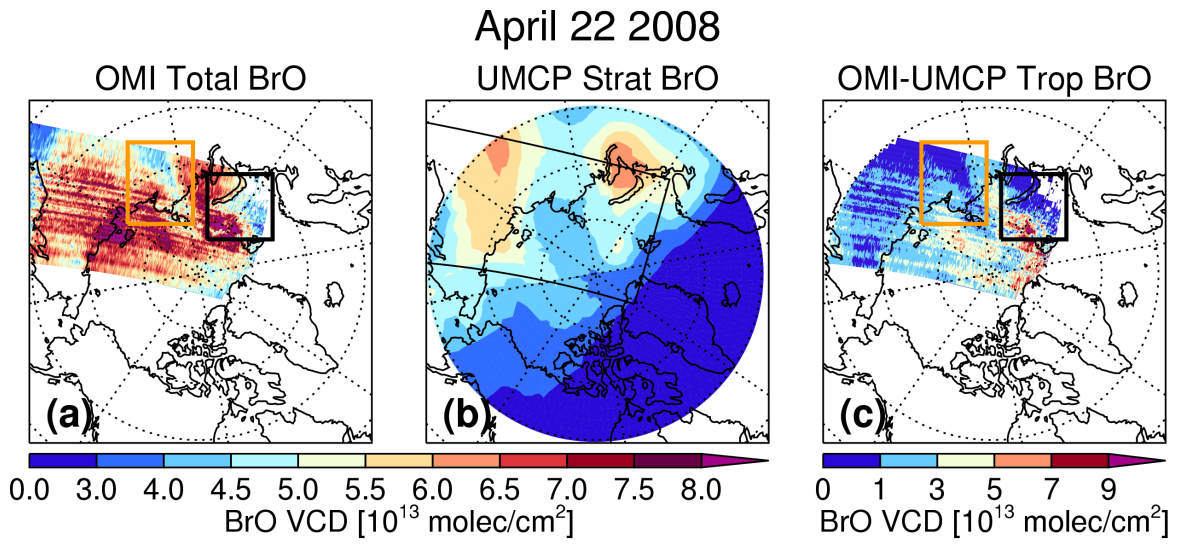

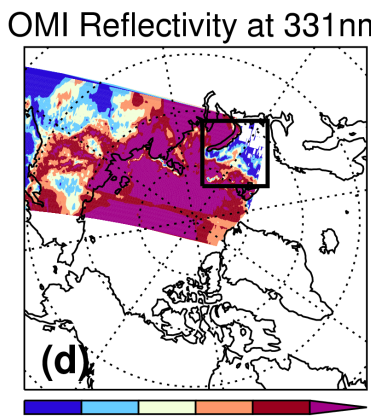

$\begin{array}{llllllll}0.0 & 0.4 & 0.5 & 0.6 & 0.7 & 0.8\end{array}$ Reflectivity
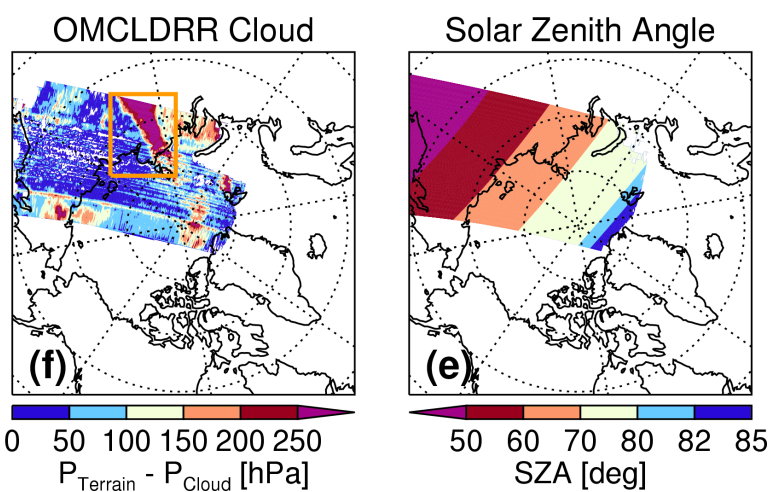

Fig. 5. Measured total vertical column BrO, reflectivity, and cloud pressure for OMI orbit 20050 at 03:23 UTC on 22 April 2008 as well as calculated stratospheric column $\mathrm{BrO}$ for the time of OMI overpass and the inferred tropospheric residual column $\mathrm{BrO}$. The panels highlight reduced tropospheric $\mathrm{BrO}$ over low albedo surfaces (black box) and in the presence of shielding clouds (orange box). See text for more details and discussion.

inference of low tropospheric $\mathrm{BrO}$ could either be a result of limited sensitivity over dark surfaces or an over-estimation of the stratospheric burden. The complicated sensitivity of satellite-derived tropospheric $\mathrm{BrO}$ to surface reflectivity and stratospheric burden requires concerted future study.

In Fig. 5, the cloud shielding effect is shown over Siberia (marked with orange rectangles), where the OMI rotational Raman cloud product reports $\Delta P_{\mathrm{c}}>250 \mathrm{hPa}$. Aqua MODIS also indicates cloud cover, with cloud top pressures between 450 and $500 \mathrm{hPa}$ (not shown). Our derived tropospheric columns over this region are significantly less than those from adjacent areas without cloud cover. This supports the presence of tropospheric $\mathrm{BrO}$ mainly at altitudes below 450 $500 \mathrm{hPa}$ and the ability of OMI and other nadir viewing sensors to capture information about tropospheric $\mathrm{BrO}$ over bright polar regions, with SZA up to $\sim 80^{\circ}$ when the sky is clear. Theys et al. (2011) also used the cloud shielding effect to infer an amount of $\mathrm{BrO}$ in the troposphere, but applied this approach only in the tropics.

For completeness, we include all data in our analysis of aircraft measurements. However, we note aircraft soundings for which observing conditions likely produce large errors in the satellite-derived tropospheric $\mathrm{BrO}$ columns. In mapping surface $\mathrm{BrO}$ enhancement events with satellite retrievals, we use only data that has good sensitivity to the troposphere: $\mathrm{SZA}<80^{\circ}, \Delta P_{\mathrm{c}}<250 \mathrm{hPa}$, and surface albedo $>0.7$.

\subsection{Uncertainty analysis}

For a single pixel, we express the uncertainty of the tropospheric $\mathrm{VCD}, \sigma_{\mathrm{VCD}_{\text {Trop }}}$, in a simplified form:

$\sigma_{\mathrm{VCD}_{\text {Trop }}}^{2}=\left(\frac{\sigma_{\mathrm{SCD}_{\text {Total }}}}{\mathrm{AMF}_{\text {Trop }}}\right)^{2}+\left(\frac{\sigma_{\mathrm{VCD}_{\text {Strat }}} \mathrm{AMF}_{\text {Strat }}}{\mathrm{AMF}_{\text {Trop }}}\right)^{2}$

(Boersma et al., 2004; De Smedt et al., 2008; Theys et al., $2011)$, where $\sigma_{\mathrm{SCD}_{\text {Total }}}$ is the uncertainty of total slant column, $\sigma_{\mathrm{SCD}_{\text {Strat }}}$ is the uncertainty of stratospheric slant column, and $\sigma_{\mathrm{AMF}_{\text {Trop }}}$ is the uncertainty of tropospheric air mass factor. This representation assumes that the different types of uncertainties are uncorrelated with each other.

We take the fitting uncertainty derived from observed minus fitted radiances for each pixel as $\sigma_{\mathrm{SCD}_{\text {Total }}}$. This assumes that the $\mathrm{SCD}_{\text {Total }}$ error has a zero mean. The average fitting uncertainty at latitudes greater than $60^{\circ} \mathrm{N}$ is about $18 \%$. Here, we do not consider systematic errors in $\mathrm{SCD}_{\text {Total }}$ or $\mathrm{VCD}_{\text {Total }}$. Systematic error will generally result 
in either a geographically uniform over-estimate or underestimate of total column $\mathrm{BrO}\left(\mathrm{VCD}_{\mathrm{Total}}\right)$. There is synergy between systematic error in $\mathrm{VCD}_{\text {Total }}$ and our prescription of the contribution of VSL species to stratospheric $\mathrm{Br}_{\mathrm{y}}$. If subsequent analysis shows the estimates of $\mathrm{VCD}_{\text {Total }} \mathrm{BrO}$ used here are biased high by a considerable margin, then clearly we must use a smaller contribution to stratospheric $\mathrm{Br}_{\mathrm{y}}$ to derive similar overall magnitude of tropospheric $\mathrm{BrO}$. However, the geographic distribution of tropospheric $\mathrm{BrO}$ will not be strongly altered due to this synergy. An exploration of the systematic error in $\mathrm{VCD}_{\text {Total }}$ and the implication for tropospheric $\mathrm{BrO}$ will occur following analysis of a ground-based, OMI BrO validation campaign conducted in Fairbanks, Alaska during April 2011.

We estimate the uncertainty of the stratospheric slant column $\left(\sigma_{\mathrm{SCD}}{ }_{\mathrm{Strat}}\right)$ by multiplying the uncertainty of the stratospheric column BrO by the stratospheric AMF. The uncertainty of the stratospheric column $\mathrm{BrO}$ results from a rootsum-squares combination of three terms: the uncertainty in chemical kinetics that govern the $\mathrm{BrO}$ to $\mathrm{Br}_{\mathrm{y}}$ ratio, the uncertainty in the dynamics that govern CFC-12 (and hence $\mathrm{Br}_{\mathrm{y}}$ due to Source Gas Injection), and the uncertainty in VSL Bry The uncertainty in chemical kinetics is evaluated by varying the rate constant of individual chemical reactions (including $J$ values) by the 1-sigma estimate of uncertainty given by Sander et al. (2006). The most important chemical term is $\mathrm{BrO}+\mathrm{NO}_{2}$ forming $\mathrm{BrNO}_{3}$; this rate constant is uncertain by about a factor of 2 at $220 \mathrm{~K}$. The uncertainty due to dynamics is found by repeating calculations for plus and minus $4 \%$ variations in the abundance of CFC-12, because comparison to aircraft observations showed CFC-12 from GEOS-5 was accurate to within $\pm 4 \%$ in the lower stratosphere (Salawitch et al., 2010). Finally, the uncertainty due to VSL $\mathrm{Br}_{\mathrm{y}}$ is set at $\pm 27 \%$, which represents the mean difference in stratospheric column BrO resulting from our approach to handling this term compared to the approach of Theys et al. (2011).

Here, we neglect the uncertainty in the tropospheric air mass factor as it is relatively small compared with the other error sources. For example, Theys et al. (2011) describe sensitivity tests that show use of a single wavelength for the weighting function profiles leads to an error of less than $5 \%$. We find that the profile dependence produces error between 7 and $13 \%$ for bright surfaces.

\section{Results and discussions}

\subsection{Comparisons of aircraft in-situ measurements with satellite retrievals}

In this section, comparisons between aircraft and satellite inferences of tropospheric column $\mathrm{BrO}$ are shown for cases where agreement is good, agreement is poor but the cause for disagreement is understood, and agreement is poor and not well understood. These comparisons are performed to evaluate the veracity of the satellite-derived tropospheric column $\mathrm{BrO}$ product. We present a series of figures for various ARCTAS and ARCPAC flights. For each, we show maps of the satellite-derived total and tropospheric columns and time series of various aircraft measurements, collocated satellitederived $\mathrm{BrO}$ data, and estimated stratospheric $\mathrm{BrO}$ amounts with vertical error bars derived using the formulation given in Sect. 3.3. Satellite-derived data are shown for all conditions (e.g. even in the presence of thick clouds that likely shield the surface). We also show plots of various parameters that affect the sensitivity of the satellite measurements to tropospheric $\mathrm{BrO}$ and note times and places where satellite observing conditions are not ideal for inferring reliable tropospheric $\mathrm{BrO}$ amounts.

\subsubsection{Cases of good agreement between satellite and in-situ data}

Figure 6a shows maps of the OMI and GOME-2 measurements of total column $\mathrm{BrO}$ as well as maps of tropospheric column BrO inferred from each satellite sensor on 17 April 2008. The track of the DC-8 and locations of $\mathrm{BrO}$ profiles, for the ARCTAS flight on this date, are marked. The bottom panel shows geographic regions of interest. OMI and GOME- 2 orbits closest in time to the ARCTAS flight are used.

The tropospheric column BrO maps have different spatial structure than maps of total column BrO. For example, total column $\mathrm{BrO}$ is highest over the north coast of Canada. These local maxima are significantly reduced in the tropospheric columns. A long tail of enhanced values near the North Pole is pronounced in the maps of tropospheric column $\mathrm{BrO}$ and is not as prominent in total column BrO. As discussed by Salawitch et al. (2010) and Theys et al. (2011), inferring tropospheric $\mathrm{BrO}$ from the total $\mathrm{BrO}$ column requires an accurate estimate of the stratospheric contribution to the total column, because variability induced by stratospheric dynamics is comparable in magnitude to variability induced by the surface release of bromine. Figure $6 \mathrm{a}$ is a perfect illustration of this point, which as noted above has been overlooked in many prior studies. Essentially all derivations of tropospheric column BrO prior to Salawitch et al. (2010) and Theys et al. (2011) relied on the use of zonally fixed stratospheric BrO, which, as first pointed out by Theys et al. (2009), will lead to large errors.

Figure $6 \mathrm{~b}$ shows time series plots of DC-8 flight data and collocated satellite measurements on 17 April 2008. We indicate time in hours relative to the starting date of the flight; therefore times greater 24:00 refer to the following day. DC8 data include aircraft altitude, in-situ $\mathrm{O}_{3}, \mathrm{CO}, \mathrm{BrO}$, active bromine and soluble bromide. Satellite data include OMIderived $\mathrm{BrO}$ columns (total and tropospheric), $\Delta P_{\mathrm{c}}$, OMI $331 \mathrm{~nm}$ reflectivity, and Aqua MODIS cloud optical thickness. Estimated errors of satellite-derived BrO columns are presented as vertical error bars. The tropopause height, as 


\section{(a) April 172008}
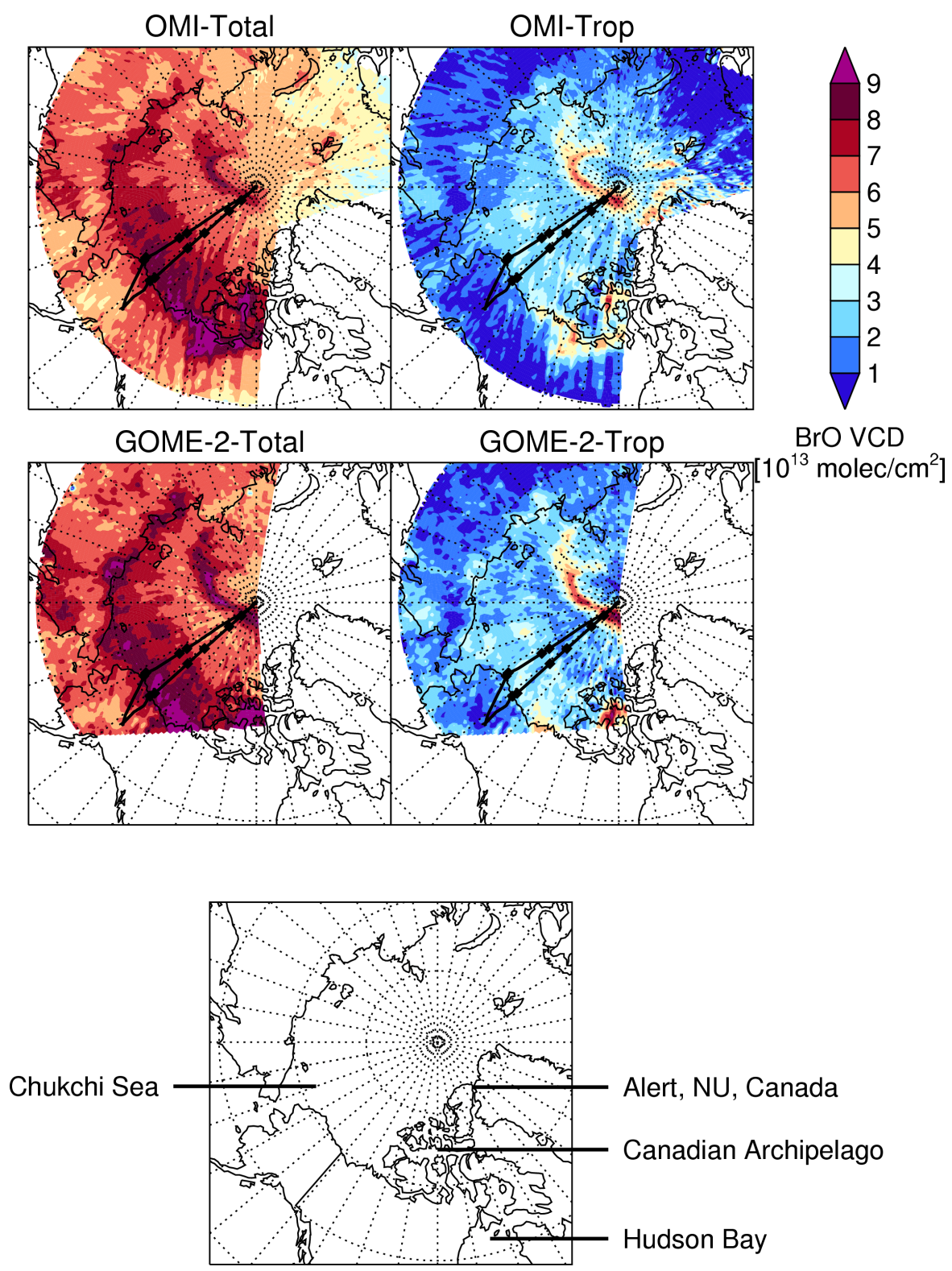

Fig. 6a. Maps on 17 April 2008 of (top left) OMI total vertical column density (VCD) of BrO, (top right) inferred OMI tropospheric VCD of BrO, (middle left) GOME-2 total VCD of BrO, and (middle right) inferred GOME-2 tropospheric VCD of BrO column. Negative values are included as dark blue. The flight track of the DC-8 on 17 April 2008 is indicated by black lines; aircraft profile locations where BrO was measured are marked with black diamonds. Geographic regions used in the paper are denoted in the bottom panel.

given in the MERRA data set, is at approximately $\sim 7 \mathrm{~km}$ during the flight (not shown). $\mathrm{CO}$ and $\mathrm{O}_{3}$ data suggest that there were no stratospheric intrusions for any of the collected tropospheric $\mathrm{BrO}$ profiles. Obvious signatures of stratospheric air (low $\mathrm{CO}$ and high $\mathrm{O}_{3}$ ) were occasionally seen, but only when the aircraft was flying near or above the tropopause.
Satellite-derived $\mathrm{BrO}$ tropospheric columns (orange line) are $\sim$ zero near Fairbanks (see top panel of Fig. 6 b). As discussed in Sects. 3.1 and 3.2, tropospheric BrO information is not reliably retrieved when surface reflectivities are less than $\sim 0.4$, which is the case near Fairbanks (see the fourth panel of Fig. 6b). 

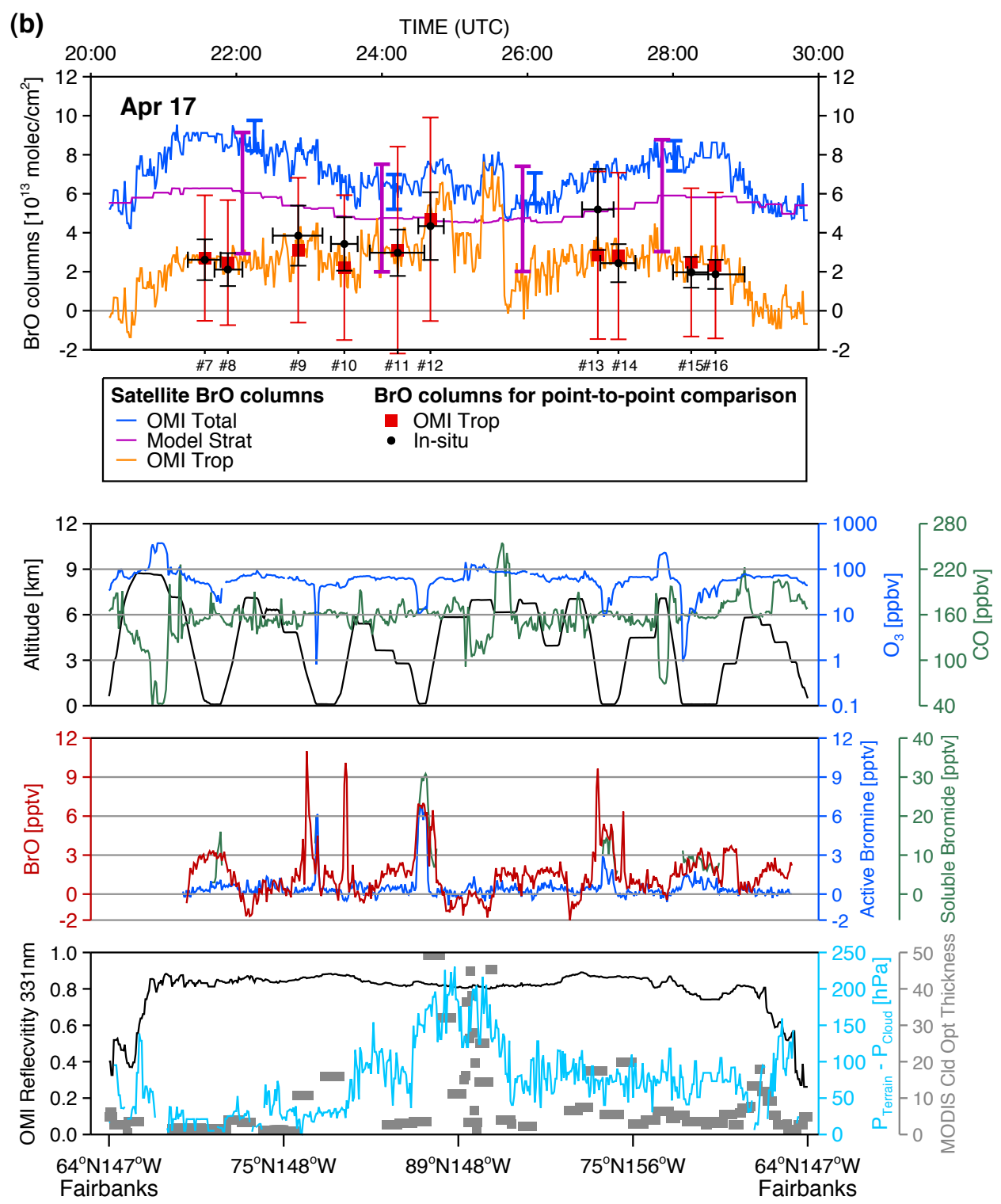

Fig. 6b. Time series plots for NASA ARCTAS DC-8 flight of 17 April 2008. For bottom three panels, line colors corresponding to the same color y axis. The top panel shows various estimates of VCD of BrO along the DC-8 flight track, including OMI total column, the modeled stratospheric column, and tropospheric columns based on aircraft in-situ measurements (black dots) as well as our analysis of OMI retrievals (red squares). The error bars of the tropospheric columns are described in the text. The two middle panels show various aircraft in-situ measurements along with the flight altitude. The bottom panel shows OMI reflectivity at $331 \mathrm{~nm}$ and cloud retrieved parameters from OMI and MODIS, as described in the text. Soluble bromide is not plotted when the reported mixing ratio was below the detection limit (1-6 pptv).

Both total and tropospheric column $\mathrm{BrO}$ show a slight dip near the pole, where the OMI and MODIS cloud products indicate shielding clouds (middle of Fig. 6b). Here, the low values of derived tropospheric $\mathrm{BrO}$ over optically thick clouds likely result from the cloud shielding effect (Theys et al., 2011). Such clouds may also reduce tropospheric $\mathrm{BrO}$ columns by slowing photochemical production of active bromine. On the other hand, high values of satellite-derived tropospheric column are found along the DC-8 flight path both before the descent in altitude at $\sim 24: 15$ UTC and after the plane has ascended. Data from both OMI and MODIS indicate optically thick clouds were present during and after the ascent. The high value of satellite-derived tropospheric column during and after ascent could be due to the presence of $\mathrm{BrO}$ above or within these clouds. Profile \#12 (see Fig. 2) shows a plume of enhanced $\mathrm{BrO}$ at about $3 \mathrm{~km}$ altitude, which could have been above the cloud deck. 


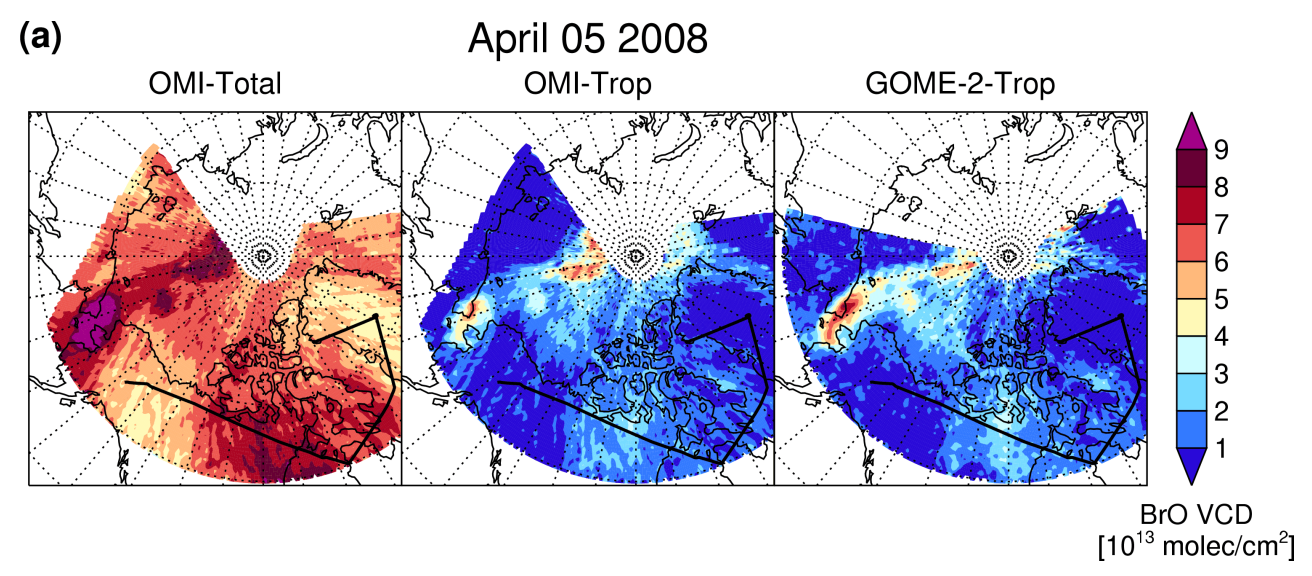

Fig. 7a. Similar to Fig. 6a but for the DC-8 flight on 5 April 2008. The GOME-2 measurement of total vertical column BrO is quite similar to OMI measurement and is therefore not shown.

In-situ tropospheric column $\mathrm{BrO}$, marked as black dots in the time series plot (the first panel of Fig. 6b), are obtained by integrating in-situ $\mathrm{BrO}$ mixing ratio profiles as described in Sect. 2.1. Uncertainties in the in-situ columns are shown as black vertical error bars. The horizontal bars indicate the distance covered by corresponding flight ascents/descents. OMI tropospheric BrO columns for point-to-point comparisons with aircraft data, shown as red squares, are obtained by averaging pixels over the corresponding flight segment.

The OMI tropospheric BrO columns exhibit a magnitude and variability similar to that of the DC-8 in-situ columns. For example, profile \#12 (see Figs. 1, 2 and 6b) reports high BrO mixing ratios from the surface to $\sim 4 \mathrm{~km}$; the OMI tropospheric BrO column (as well as GOME-2, shown in Fig. 6a but not in Fig. 6b) is also relatively high at the same location.

However, some discrepancies appear, perhaps because the aircraft captures small scale features that the satellite observations cannot resolve. For example, in-situ profile \#13 (see Figs. 2 and $6 \mathrm{~b}$ ) shows a relatively large value for tropospheric column $\mathrm{BrO}$, caused by enhanced $\mathrm{BrO}$ mixing ratios in a layer near $2 \mathrm{~km}$. This could be a local event as the nearby aircraft column \#14 does not show such an enhancement. The satellite retrieval agrees well with profile \#14 but underestimates the abundance of $\mathrm{BrO}$ measured in profile \#13. Overall, OMI tropospheric column $\mathrm{BrO}$ quantitatively agrees with the DC-8 in-situ column $\mathrm{BrO}$ to within the respective estimated uncertainties. The comparison between satellite and in-situ tropospheric column BrO for this flight is further quantified by Liao et al. (2011b). These comparisons demonstrate the ability of OMI and GOME-2 to capture the magnitude and spatial distribution of tropospheric column $\mathrm{BrO}$ over bright surfaces for clear conditions.

\subsubsection{Examination of differences between satellite-derived and in-situ tropospheric columns of BrO}

We next describe two cases of apparent inconsistency between satellite and in-situ observations. Figures $7 \mathrm{a}$ and $7 \mathrm{~b}$ show data corresponding to the DC-8 flight on 5 April 2008. In-situ measurements did not detect ozone depletion or high bromine over Hudson Bay, whereas OMI and GOME-2 both report high total column $\mathrm{BrO}$ over vast regions of eastern Canada including Hudson Bay (Salawitch et al., 2010). BrO measurements were not available to produce profiles for this flight, but active bromine and soluble bromide were reported. Figure $7 \mathrm{~b}$ shows that the derived tropospheric $\mathrm{BrO}$ column from OMI is low over Eastern Canada, where the total column is high. Similar results are found for GOME-2 (Fig. 7a). The OMI measurement of total column BrO shows very similar magnitude and structure as the calculated stratospheric column BrO. This suggests that the elevated total column $\mathrm{BrO}$ over Eastern Canada could be a consequence of high stratospheric columns. Furthermore, the in-situ $\mathrm{CO}$ and $\mathrm{O}_{3}$ measurements indicate no evidence of stratospheric air below $6 \mathrm{~km}$ altitude in ascending or descending flight tracks near Hudson Bay.

Figures $8 \mathrm{a}$ and $8 \mathrm{~b}$ show similar maps and time series, respectively, for the DC-8 flight on 8 April 2008. GOME-2 observations during this flight are not available. Aircraft insitu $\mathrm{BrO}$ measurements are also not available for this flight. This makes it difficult to evaluate the validity of the OMIderived $\mathrm{BrO}$ tropospheric columns. The aircraft observed a severe ozone depletion event $\left(\left[\mathrm{O}_{3}\right]<1 \mathrm{ppbv}\right)$ and high levels of active bromine and soluble bromide near Alert (marked as black square), whereas the OMI total column $\mathrm{BrO}$ is relatively low and the inferred OMI tropospheric column $\mathrm{BrO}$ is at or near background levels. The ODE observed by the DC- 8 on 8 April 2008 is thus not apparent in the satellite measurement of $\mathrm{BrO}$ on this date. 

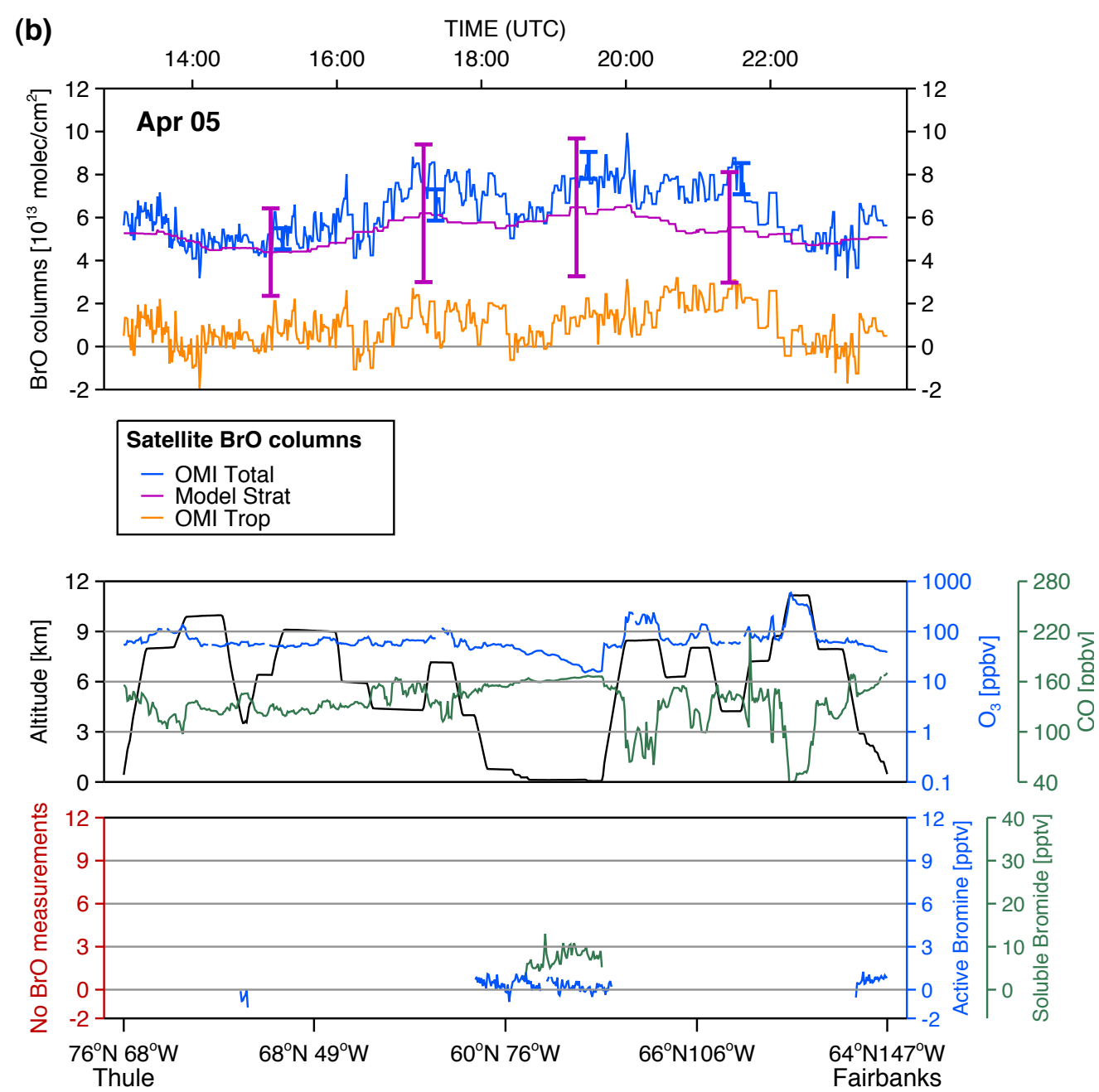

Fig. 7b. Similar to Fig. 6 b but for the DC-8 flight on 5 April 2008. Aircraft in-situ BrO measurements are not available for this flight because $\mathrm{BrO}$ was below the detection limit.

There are segments where inferred OMI tropospheric $\mathrm{BrO}$ is negative, such as the early time period of 8 April 2008 (see Fig. 8b). These values of negative $\mathrm{BrO}$ could be indicative of an over-correction for the stratospheric column, measurement noise for total column $\mathrm{BrO}$, or some other error in calculation. Overall, we do not find extended regions of negative tropospheric $\mathrm{BrO}$ (either spatially or temporally).

As described in Eqs. (3), (4), and (5), $\mathrm{BrO}$ catalyzes the loss of ozone and, at the same time, $\mathrm{BrO}$ is produced by reaction of $\mathrm{Br}$ with $\mathrm{O}_{3}$. This suggests that high $\mathrm{BrO}$ concentrations cannot be maintained if $\mathrm{O}_{3}$ is completely depleted, even though plenty of active bromine may be available. This explanation is consistent with other observations (e.g. Hausmann and Platt, 1994; Tuckermann et al., 1997; Neuman et al., 2010; Frieß et al., 2011) that show high BrO concentrations only when ozone is partially depleted. The presence of a severe ozone depletion event is therefore indicative of an expectation of little or no enhancement of tropospheric $\mathrm{BrO}$, despite the presence of large amounts of active bromine and soluble bromide. Liao et al. (2011a) also discuss the relationship between $\mathrm{O}_{3}$ and $\mathrm{BrO}$; little $\mathrm{BrO}$ exists when $\mathrm{O}_{3}$ is low due to the partitioning between $\mathrm{Br}$ and $\mathrm{BrO}$.

OMI tropospheric column $\mathrm{BrO}$ shows enhancements in the vicinity of the 8 April 2008 ozone depletion event, during the $36 \mathrm{~h}$ time period prior to this flight (not shown). This enhancement is likely connected with the nearly complete removal of ozone observed by the DC- 8 aircraft.

\subsubsection{Cases of disagreement between satellite and in-situ data}

Figure 9a shows maps of satellite-derived $\mathrm{BrO}$ columns and the flight track of the NOAA ARCPAC WP-3D on 19 April 2008. The OMI and GOME-2 data both indicate enhanced total and tropospheric columns of $\mathrm{BrO}$ over the Chukchi Sea. The aircraft flew into the area of elevated satellite-derived 
(a) April 082008

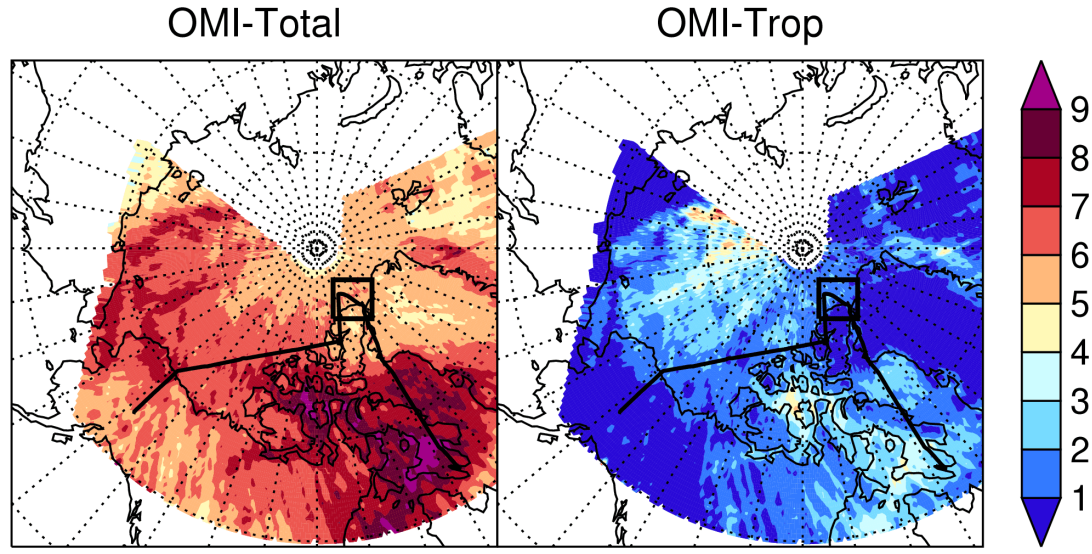

$\mathrm{BrO}$ VCD

$\left[10^{13} \mathrm{molec} / \mathrm{cm}^{2}\right]$

Fig. 8a. Similar to Fig. 6a but for the DC-8 flight on 8 April 2008. GOME-2 data are not available for this day. The location of severe ozone depletion and high active bromine sampled by the DC- 8 is marked by the black squares.
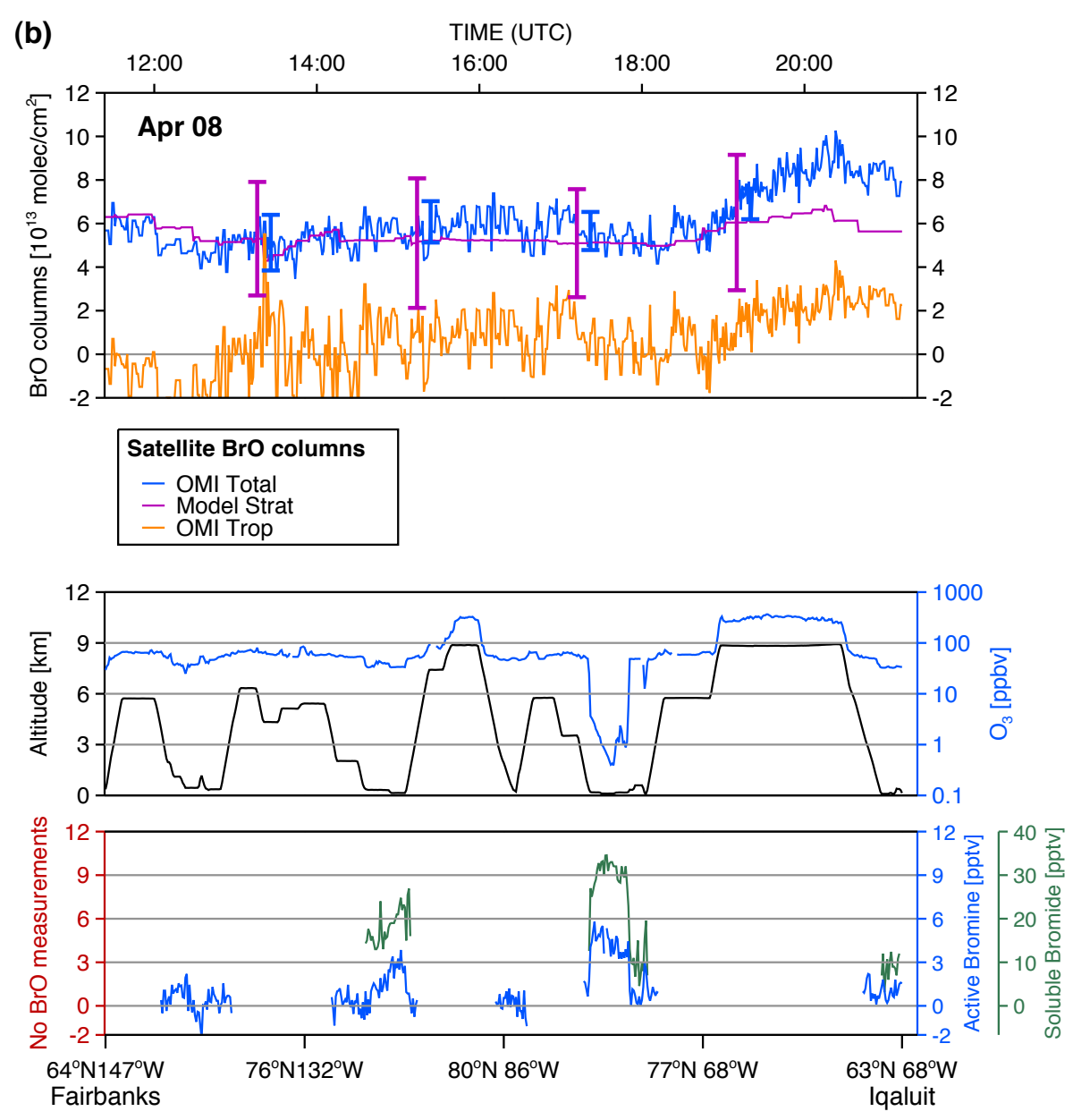

Fig. 8b. Similar to Fig. 7b but for the DC-8 flight on 8 April 2008. 
(a) April 192008

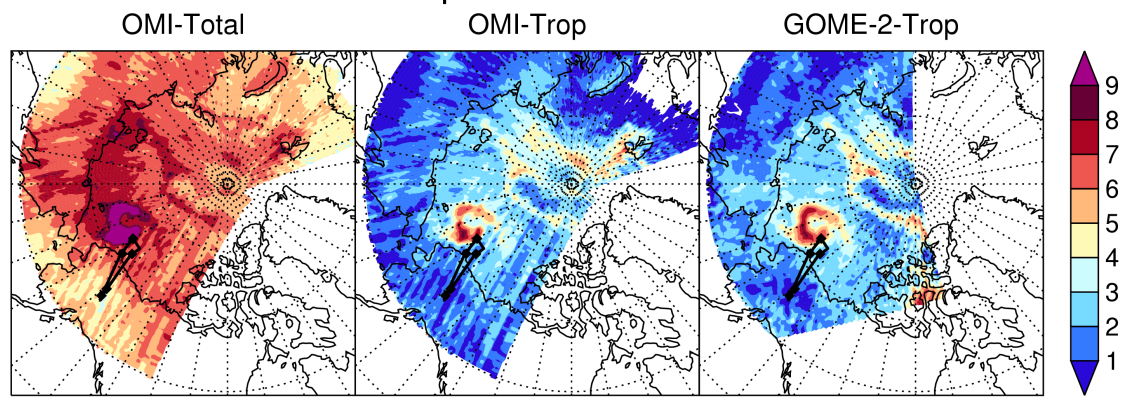

BrO VCD

$\left[10^{13} \mathrm{molec} / \mathrm{cm}^{2}\right]$

Fig. 9a. Similar to Fig. 7a but for the WP-3D flight of 19 April 2008.
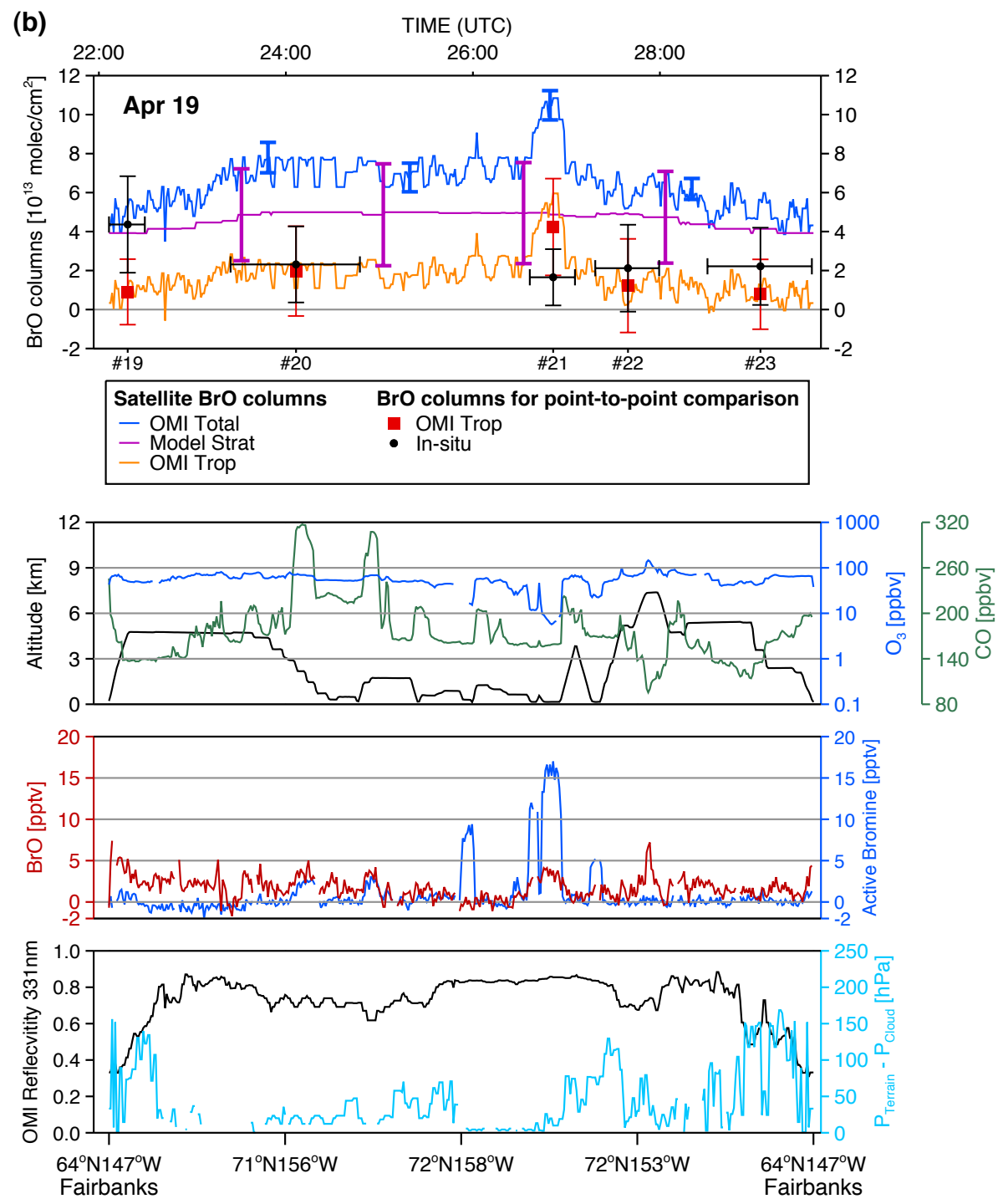

Fig. 9b. Similar to Fig. 6b but for the WP-3D flight on 19 April 2008. Soluble bromide was not measured from the WP-3D. 
(a)

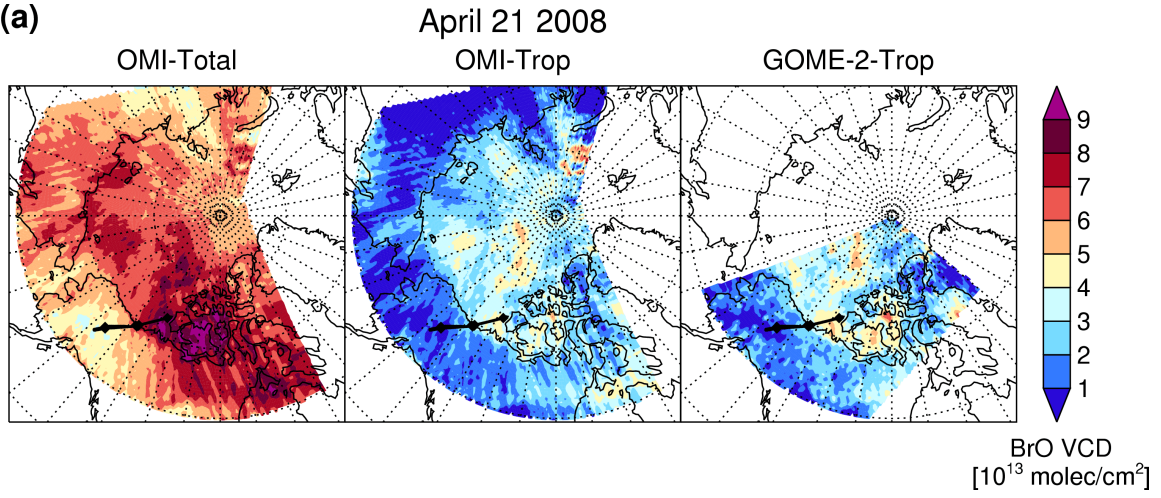

Fig. 10a. Similar to Fig. 7a but for the WP-3D flight of 21 April 2008.

tropospheric column $\mathrm{BrO}$ at the northernmost extent of the track.

Figure $9 \mathrm{~b}$ shows time series plots for the flight of 19 April 2008. Two types of disagreement between in-situ and satellite tropospheric column $\mathrm{BrO}$ are observed. First, satellitederived tropospheric column $\mathrm{BrO}$ is considerably less than the in-situ column over surfaces with moderate reflectivity in the presence of clouds. For example, the OMI estimate is less than the WP-3D columns (\#19 and \#23) near Fairbanks. These observations were obtained in a region where the surface albedo is between 0.4 and 0.6 , in the presence of low level clouds. This type of disagreement may be expected from the sensitivity studies described in Sect. 3.2. It is a challenge for satellite sensors to accurately retrieve tropospheric $\mathrm{BrO}$ over a moderately reflective surface in the presence of clouds.

The second type of disagreement during this flight is illustrated by profile \#21 (see Figs. 1, 2 and 9b), where both OMI and GOME- 2 tropospheric column $\mathrm{BrO}$ are significantly enhanced (only OMI is shown in the first panel of Fig. 9b), whereas the in-situ BrO column does not show evidence of enhancement. Artifacts from clouds or surface albedo are not the likely explanation for this disagreement, as the surface was bright and no clouds are evident in $\Delta P_{\mathrm{c}}$ (fourth panel, Fig. 9b). The highest level of active bromine is observed from the aircraft sensor at the same location where tropospheric column $\mathrm{BrO}$ from both satellite sensors show enhancements. $\mathrm{O}_{3}$ mixing ratios of $\sim 10 \mathrm{ppbv}$ suggest the aircraft sampled a partial ozone depletion event (e.g. Ridley et al., 2003). Prior DOAS observations in the Arctic suggest that $\mathrm{BrO}$ should still be present for $\mathrm{O}_{3}$ levels of $\sim 10 \mathrm{ppbv}$ (Hausmann and Platt, 1994; Tuckermann et al., 1997). The disagreement between satellite and aircraft $\mathrm{BrO}$ could be related to the different spatial scales, and/or vertical coverage spanned by the respective instruments: the aircraft does not observe the complete profile and the field of view encompassed by the satellite covers a larger area than that sampled by the airplane. The aircraft may have missed an important part of the $\mathrm{BrO}$ profile as the minimum sampled height was
$151 \mathrm{~m}$ above the surface. Timing may also be a possible explanation for the disagreement, as the aircraft flew near the location of the enhancement about five hours after the OMI overpass and about three hours after that of GOME-2.

Our analysis indicates that the large enhancement in total column BrO seen by OMI and GOME- 2 over the Chukchi Sea on 19 April 2008 was tropospheric in origin, rather than stratospheric. The WP-3D aircraft recorded highly elevated active bromine and partially depleted $\mathrm{O}_{3}$ near the surface at this precise location, indicating recent association with elevated $\mathrm{BrO}$. It is possible the satellite perturbation was caused by the presence of $\mathrm{BrO}$ at higher altitudes than those sampled by the aircraft at this location. By the time the aircraft reached $3 \mathrm{~km}$ altitude, it had left the region of highly elevated satellite BrO (terminal point of profile \#23 (see Figs. 2 and $9 b)$ ). Salawitch et al. (2010) presented an analysis of groundbased Max DOAS observations of BrO for April 2008 that, together with ARCTAS and ARCPAC BrO profiles, showed important contributions to column $\mathrm{BrO}$ often originate within the troposphere from altitudes above the top of the planetary boundary layer.

Figures 10a and 10b show maps of the $\mathrm{BrO}$ columns and time series plots for the NOAA WP-3D flight of 21 April 2008, respectively. The maps show enhanced OMI total column $\mathrm{BrO}$ over the north shore of Canada and the Canadian Archipelago. The stratospheric model shows only a slight enhancement for these regions; the subtraction of the stratospheric model from the OMI column shows significant levels of tropospheric column $\mathrm{BrO}$ for much of the flight segment. Time series plots indicate that WP-3D in-situ columns \#25, \#26, and \#27 (see Figs. 1, 2 and 10b) are lower than the OMI tropospheric column, but the differences are not significant given the uncertainties in OMI and in-situ tropospheric columns (i.e., error bars overlap). However, the absolute magnitude of the OMI tropospheric column is about a factor of 3 larger than the in-situ $\mathrm{BrO}$ column. There is, however, good agreement between in-situ column \#28 and the satellite-based estimate. 

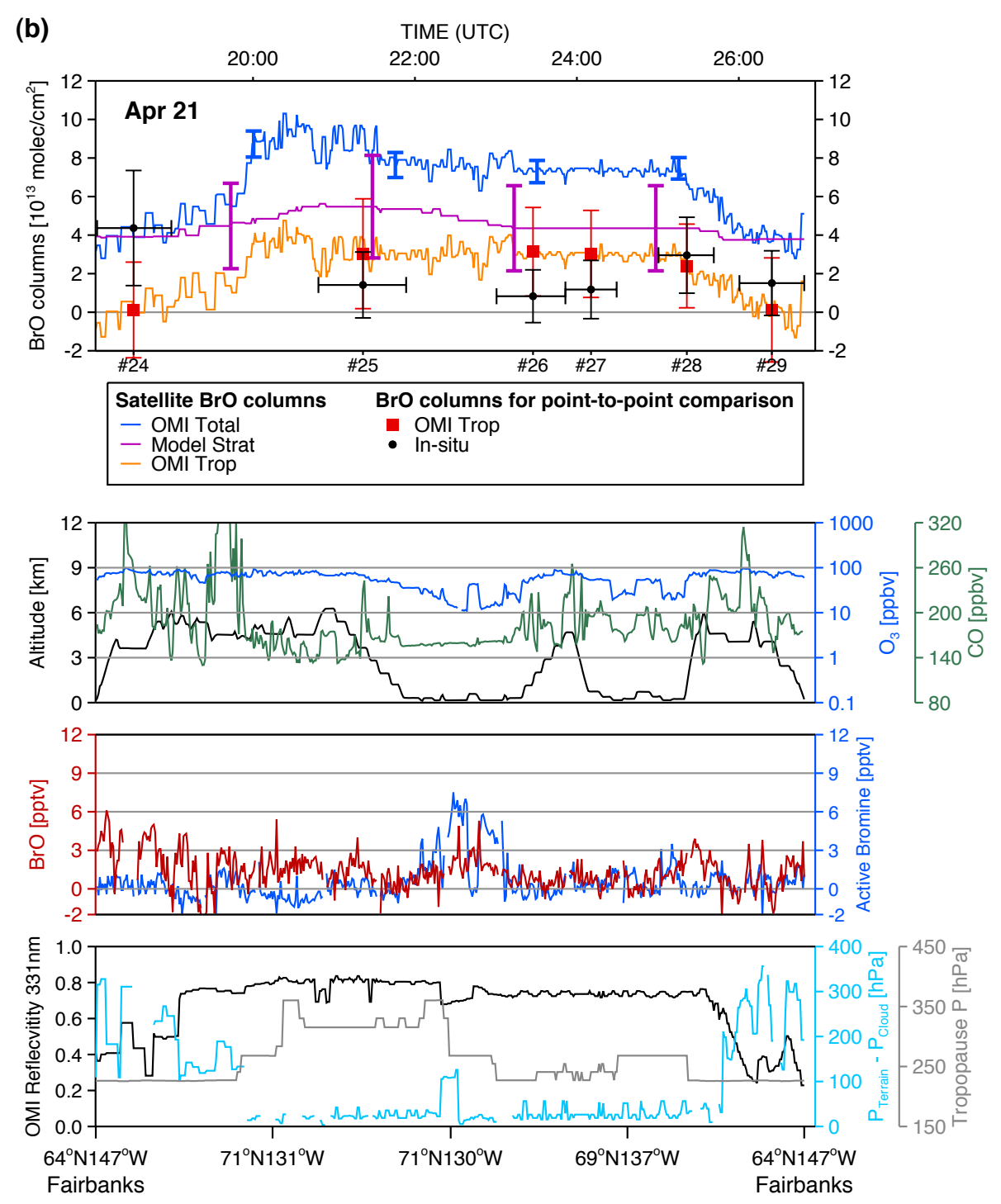

Fig. 10b. Similar to Fig. 9b but for the WP-3D flight on 21 April 2008, with tropopause pressure added (bottom panel).

WP-3D profiles \#26, \#27, and \#28 (see Figs. 1, 2 and 10b) were collected in close proximity (see Fig. 1), but show a large variation in the column amounts. As noted above, the profile \#28 column agrees well with the satellite-based column whereas the other two in-situ based $\mathrm{BrO}$ columns are lower than the satellite-based estimates. As discussed above for other flights, this result may be explained by the fact that the aircraft captures small-scale spatial features while the satellite observes larger scales.

The overestimation of the tropospheric column $\mathrm{BrO}$ by OMI, compared to in-situ columns for profile \#25, \#26, and \#27 (see Figs. 1, 2 and 10b), could potentially be explained by a stratospheric column that is not fully removed from the total column. One factor not considered in our analysis is irreversible, cross-tropopause exchange of air parcels with elevated levels of $\mathrm{Br}_{\mathrm{y}}$ from the stratosphere to the tro- posphere (STE). Such transport events occur on the western flank of Arctic low pressure systems (Salawitch et al., 2010, and references therein). If the satellite signal were to originate from STE of $\mathrm{Br}_{\mathrm{y}}$, the $\mathrm{BrO}$ signal associated with such air parcels may not have been sampled by the WP-3D because the maximum altitudes of the WP-3D profiles \#25, \#26 and \#27 (6 km) is well below the height of the tropopause $(10.5 \mathrm{~km})$. Future measurement of profiles of $\mathrm{BrO}$ from near the surface to the lowermost stratosphere, in the footprint of a satellite sensor after passage of an airmass with a low altitude tropopause, are needed to assess the importance of STE of bromine on the interpretation of the satellite record. 




Fig. 11. OMI tropospheric BrO VCD for different orbits (UTC time as indicated) from 16 to 18 April 2008.

\subsection{BrO explosions observed with satellites}

Events of rapid enhancement of tropospheric column $\mathrm{BrO}$ are apparent from OMI and GOME-2 observations after adjustment for the stratospheric burden of $\mathrm{BrO}$, for the time period mid-March to late April 2008. The NASA DC-8 aircraft flew into an area of enhanced tropospheric column $\mathrm{BrO}$ near the North Pole on 17 April 2008 (Fig. 6a) and the NOAA WP-3D aircraft flew near another tropospheric $\mathrm{BrO}$ enhancement on 19 April 2008 (Fig. 9a). Here we examine the event near the North Pole on 17 April 2008 and similar events in more detail using only OMI retrievals. The wide orbital swath and high spatial resolution of OMI, in addition to its frequent observations at high latitudes, provide a unique view of the temporal evolution of these events.

Figure 11 shows the evolution of a tropospheric $\mathrm{BrO}$ enhancement event ("BrO explosion") observed from 16 to 18 April 2008. Here, we only show observations when the following conditions are met, to provide reliable tropospheric $\mathrm{BrO}$ information as discussed in Sect. 3.2: $\mathrm{SZA}<80^{\circ}$, reflectivity $>0.7$, and $\Delta P_{\mathrm{c}}<250 \mathrm{hPa}$. The stratospheric column has been removed, as discussed in Sect. 3.1, using photochemical model output for the VSL $\mathrm{Br}_{\mathrm{y}}=7 \mathrm{ppt}$ simulation, for the local solar time of each OMI pixel. The major 


\section{1:25Z April 172008 OMI Orbit 19976}
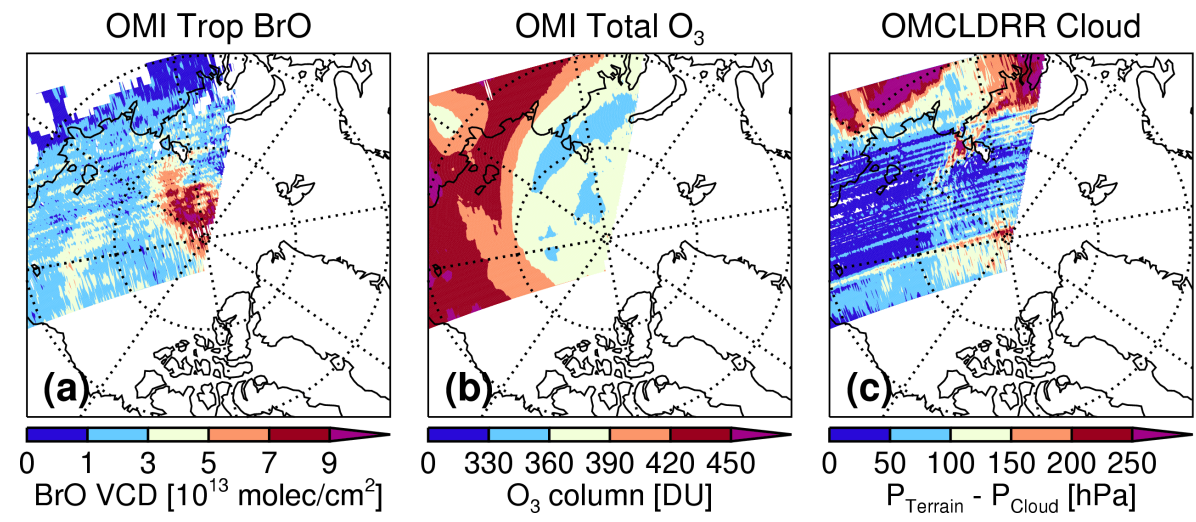

Fig. 12. (a) OMI tropospheric BrO VCD; (b) OMI total ozone column; (c) terrain minus cloud pressure for OMI orbit 19976 on 17 April 2008.

activation of $\mathrm{BrO}$ starts at $~ 22: 00$ UTC on 16 April and lasts for $\sim 30 \mathrm{~h}$. We see activations near the North Pole and Canadian Archipelago. The spatial features of the elevated tropospheric column BrO change rapidly, with significant variations over the course of a day.

We have ruled out a stratospheric origin for the enhanced total column BrO observations near the North Pole and Canadian Archipelago on these days. Since stratospheric $\mathrm{BrO}$ and $\mathrm{O}_{3}$ columns exhibit a significant correlation (Theys et al., 2009; Salawitch et al., 2010), the OMI measurement of total $\mathrm{O}_{3}$ column can be used as a proxy for the spatial pattern of stratospheric column BrO. The comparison of the OMI tropospheric $\mathrm{BrO}$ column with the $\mathrm{OMI}$ total $\mathrm{O}_{3}$ column shown in Fig. 12 indicates lack of correlation. Thus, the elevated region of total column $\mathrm{BrO}$ is not of stratospheric origin. Figure 12 also shows few shielding clouds near the areas with high $\mathrm{BrO}$ columns.

Figure 13 shows three tropospheric $\mathrm{BrO}$ enhancement events during April 2008 along with maps of sea level pressure, wind speed at $2 \mathrm{~m}$ altitude, and planetary boundary layer height from MERRA for the closest synoptic hour. For these events, the locations of enhanced $\mathrm{BrO}$ columns are coincident with high near-surface wind speeds (3rd column) that are geostrophically consistent with localized low pressure systems. Neuman et al. (2010) also note high wind speed along the flight paths in conjunction with high concentrations of active bromine. Our analysis is consistent with the suggestion that strong surface winds associated with low pressure systems can trigger bromine activation via blowing snow (Yang et al., 2008; Jones et al., 2009, 2010).

Figure 13 also shows that the spatial structure of high tropospheric column $\mathrm{BrO}$ is similar to that of the planetary boundary layer (PBL) height, although there is not always a precise alignment of these features. At high latitudes where the meteorological analysis is driven primarily by satellite data, the MERRA fields may contain displacement or other errors, particularly in near-surface fields. The following discussion should therefore be considered somewhat speculative in light of these uncertainties. We provide an animated visualization as a Supplement to depict evolution of enhanced tropospheric column $\mathrm{BrO}$, sea level pressure, wind speed at $2 \mathrm{~m}$ and planetary boundary layer height from 16 to 18 April 2008.

Neuman et al. (2010) reported a temperature inversion at $500 \mathrm{~m}$ during the $\mathrm{BrO}$ activation event of 19 April 2008, more or less consistent with the MERRA PBL height. Bromine chemistry may be related to PBL height as follows: $\mathrm{BrO}$ concentrations are controlled in large part by $\mathrm{O}_{3}$; a sufficient amount of $\mathrm{O}_{3}$ is necessary to maintain high $\mathrm{BrO}$ concentrations as explained in Sec. 4.1.2. Ozone is quickly consumed in a shallow boundary layer during bromine activation (Lehrer et al., 2004; Anderson and Neff, 2008). When $\mathrm{O}_{3}$ is substantially depleted, production of $\mathrm{BrO}$ will cease and $\mathrm{BrO}$ will be destroyed by various reactions, including those in Eq. (4). On the other hand, the $\mathrm{O}_{3}$ loss rate is quadratic in $\mathrm{BrO}$, so a deeper boundary layer could slow down the chemical removal of $\mathrm{O}_{3}$ as $\mathrm{BrO}$ is diluted.

The second row of Fig. 13 illustrates an event at 00:30 UTC on 18 April 2008 and the third row is for an event at 22:40 UTC on 19 April 2008. The two OMI orbits presented are closest in time to airplane flights into the elevated $\mathrm{BrO}$ and active bromine layers (profile \#12 from DC-8 and \#21 from WP-3D, respectively (see Figs. 1, 2, 6b and 9b)). The locations of the profiles are shown as black diamonds on the maps of tropospheric BrO. The aircraft profiles of temperature, $\mathrm{BrO}$ mixing ratio, and active bromine mixing ratio are presented in the last column. Aircraft measurements show enhanced active bromine in the near-surface layer for both flights and enhanced amounts of $\mathrm{BrO}$ for the 18 April flight. Satellite-derived tropospheric $\mathrm{BrO}$ enhancements are 


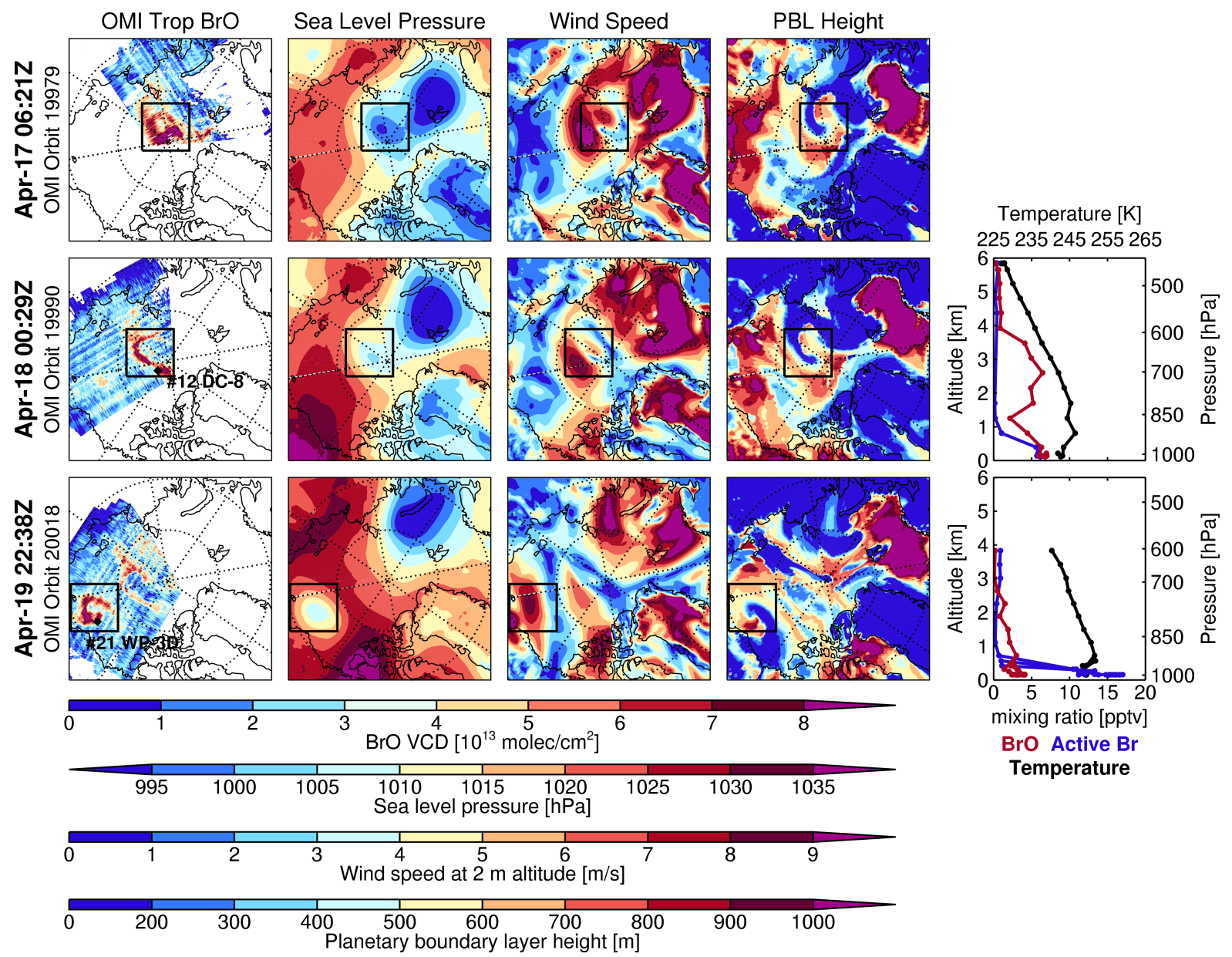

Fig. 13. First column: OMI tropospheric BrO VCD; Second column: MERRA sea level pressure; third column: MERRA wind speed at $2 \mathrm{~m}$ altitude; fourth column: MERRA planetary boundary layer height; fifth column: aircraft in-situ profiles of BrO (red), active bromine (blue) and temperature (black). The rows correspond to OMI orbits. We show results for orbit 19979 on 17 April 2008 (top row), orbit 19990 on 18 April 2008 (middle row), and orbit 20018 on 19 April 2008 (bottom row). Aircraft profiles were not obtained during the time that the satellite data shown in the top row were acquired. An animated GIF of this figure is available in Supplemental Material.

closely related to near-surface parameters including sea level pressure, wind speed at $2 \mathrm{~m}$, and PBL height. This observation suggests that the $\mathrm{BrO}$ activations originate at the surface, which of course is consistent with prior expectation. For the event on 18 April, a tail of enhanced BrO column exists parallel to the wind direction inferred from sea level pressure. Begoin et al. (2010) suggested long range transport of tropospheric $\mathrm{Br}_{\mathrm{y}}$ for plumes in which recycling of bromine from condensed to gas phase sustains elevated BrO. The profile for $\mathrm{BrO}$ measured on 18 April by the DC- 8 instrument (Fig. 13) also shows enhancements in the free troposphere, above the top of the PBL height $(\sim 500 \mathrm{~m})$. Simultaneous profiles of $\mathrm{CO}$ and $\mathrm{O}_{3}$ (not shown here, see Fig. 6b) imply no stratospheric influence. The existence of elevated $\mathrm{BrO}$ above the top of the PBL could be due to vigorous convection over ice leads driven by warm exposed water, with $\mathrm{BrO}$ then dispersed horizontally by prevailing winds (Simpson et al., 2007b; Salawitch et al., 2010). Our results are consistent with a surface origin of elevated $\mathrm{BrO}$ as well as transport of $\mathrm{Br}_{\mathrm{y}}$ enriched air parcels away from the source of origin. Indeed, an animation of the panels in Fig. 13 (see Supplement) provides compelling evidence for this behavior.

\section{Conclusions}

We have estimated tropospheric column $\mathrm{BrO}$ for April 2008 from OMI and GOME-2 retrieved total column $\mathrm{BrO}$ retrievals and a model simulation of the stratospheric column BrO. The sensitivity of satellite radiances to tropospheric $\mathrm{BrO}$ depends on various parameters, such as surface albedo, solar zenith angle (SZA), viewing zenith angle (VZA), the shape of the BrO profile, and the presence of clouds. We have quantified these dependences with a radiative transfer model. A detailed comparison is provided between 
tropospheric column $\mathrm{BrO}$ found from OMI and GOME-2 measurements of total column $\mathrm{BrO}$ and tropospheric column $\mathrm{BrO}$ computed from in-situ observations of $\mathrm{BrO}$ and related species acquired by instruments aboard the DC- 8 and WP-3D aircraft during the ARCTAS and ARCPAC field campaigns.

Our analysis shows that retrievals of total column $\mathrm{BrO}$ from OMI and GOME-2, combined with a model estimate of stratospheric column $\mathrm{BrO}$, can be used to retrieve realistic estimates of the magnitude and spatial variations in tropospheric column $\mathrm{BrO}$ provided that proper observing conditions are met. These conditions include bright surfaces (albedos $\geq \sim 0.7$ ), low SZAs $\left(\leq \sim 80^{\circ}\right)$, and the absence of optically thick clouds. For the flight of 17 April 2008, satellite-derived tropospheric column BrO shows enhancements where the DC-8 reports intense bromine activation and moderate ozone depletion. The satellite and aircraft based measurements of tropospheric column $\mathrm{BrO}$ are in close quantitative agreement on 17 April 2008, particularly for DC-8 flight segments over bright surfaces in clear conditions. In contrast to prior expectation based on DOAS measurements, the tropospheric burden of $\mathrm{BrO}$ based on the aircraft profiles was distributed over a broad range of altitudes and was not restricted to the planetary boundary layer. The presence of elevated $\mathrm{BrO}$ above the PBL might be driven by convection over warm exposed water in regions of ice leads, with $\mathrm{BrO}$ then dispersed by prevailing winds (Simpson et al., 2007b; Salawitch et al., 2010).

Many prior studies have used a zonally symmetric representation of stratospheric $\mathrm{BrO}$ to derive tropspheric $\mathrm{BrO}$ from satellite observations. As put forth by Theys et al. (2009), Salawitch et al. (2010), and Theys et al. (2011) and reinforced here, this is a deeply flawed assumption. For the DC-8 flight of 5 April 2008, regions of enhanced total column BrO observed by OMI and GOME-2 near Hudson Bay are attributed to compression of stratospheric air associated with a low altitude tropopause, as neither the aircraft nor the satellite based measurements of tropospheric column $\mathrm{BrO}$ show enhancements. The regions of enhanced tropospheric column BrO inferred from OMI and GOME-2 on 5 and 17 April 2008 are not readily apparent in maps of total column $\mathrm{BrO}$ because stratospheric variability imparts variations in column $\mathrm{BrO}$ comparable in magnitude to the tropospheric signal. Use of a zonally symmetric representation of stratospheric column $\mathrm{BrO}$ prevents the proper identification of the tropospheric BrO burden (e.g. Theys et al., 2009; Salawitch et al., 2010; Theys et al., 2011). Caution should be applied when interpreting satellite-derived tropospheric $\mathrm{BrO}$ for SZA greater than $\sim 80$ degrees because, under these conditions satellite radiances have decreased sensitivity to absorption by tropospheric $\mathrm{BrO}$ (Fig. 4).

Satellite and aircraft measurements of tropospheric column $\mathrm{BrO}$ do not always exhibit good agreement, at times for reasons that seem well understood and at other times for reasons that are unclear but may be related to differences in the timing or spatial coverage of the respective observations.
For the severe ozone depletion event observed by the DC-8 near Alert on 8 April 2008, neither OMI total column BrO column nor OMI tropospheric column $\mathrm{BrO}$ were elevated. Atmospheric conditions were favorable for the remote sensing from space of tropospheric $\mathrm{BrO}$ near Alert on this date (e.g. clear skies, high surface reflectivity). We believe the lack of a signal for OMI tropospheric column $\mathrm{BrO}$ near Alert on 8 April is consistent with our understanding of bromine chemistry: the production of $\mathrm{BrO}$ diminishes when ozone is severely depleted (e.g. Hausmann and Platt, 1994; Tuckermann et al., 1997). Hence, the association of elevated tropospheric column $\mathrm{BrO}$ and depleted $\mathrm{O}_{3}$ is expected to be much stronger for a partial ozone depletion event (ODE) than a major ODE. Tropospheric column BrO from OMI does show an enhancement, near Alert, $36 \mathrm{~h}$ prior to the major ODE. The aircraft may have been capturing very small scale variability (several nearby profiles showed large differences) compared to space-based observations. Finally, aircraft observations generally did not sample the altitude region where stratosphere to troposphere transport of active bromine associated with air parcels with elevated levels of inorganic bromine could potentially be affecting the satellite measurement of column BrO.

We examined several events of rapid enhancement of tropospheric column $\mathrm{BrO}$ observed by OMI. Observations at high latitudes from this polar-orbiting, sun-synchronous satellite provide a unique illustration of the rapid temporal evolution of $\mathrm{BrO}$ activation because orbital periods are about 100 min apart. Our analysis indicates that $\mathrm{BrO}$ activation events occurring on 16, 17, and 18 April 2008 are related to near-surface parameters such as low pressure systems, strong surface winds, and/or high planetary boundary layer. The satellite measurements reveal horizontal transport of activated bromine away from the source of origin, and the aircraft measurements show disbursement of $\mathrm{BrO}$ within the free troposphere. The strong quantitative agreement between OMI and aircraft tropospheric column BrO on 17 April 2008 supports the validity of the rapid time evolution, on synoptic scales, revealed by the OMI tropospheric $\mathrm{BrO}$ product. The events on 17, 18, and 19 April suggest bromine activation via high winds over snow (Yang et al., 2008; Jones et al., 2009, 2010) as well as long range transport of $\mathrm{Br}_{\mathrm{y}}$ by surface winds (Begoin et al., 2010).

\section{Supplement related to this article is available online at: http://www.atmos-chem-phys.net/12/1255/2012/ acp-12-1255-2012-supplement.zip.}

Acknowledgements. This work was supported by the National Aeronautics and Space Administration (NASA) IPY, ARCTAS, and Aura science team programs, National Oceanic and Atmospheric Administration (NOAA) ARCPAC program, GEST GSSP program, and Smithsonian Institution. The authors are grateful to the NASA GMAO reanalysis processing teams as well as the GOME-2, OMI, and MODIS data processing teams 
for providing data sets. The authors also appreciate numerous helpful discussions with George Mount. We also thank Nicolas Theys for sharing his calculations of stratospheric column $\mathrm{BrO}$ and for many helpful email exchanges. Finally, the authors express special thanks to the two anonymous referees and editor Jan W. Bottenheim for valuable comments that improved this paper.

Edited by: J. W. Bottenheim

\section{References}

Anderson, P. S. and Neff, W. D.: Boundary layer physics over snow and ice, Atmos. Chem. Phys., 8, 3563-3582, doi:10.5194/acp-83563-2008, 2008.

Ariya, P., Dastoor, A. P., Amyot, M., Schroeder, W. H., Barrie, L., Anlauf, K., Raofie, F., Ryzhkov, A., Davignon, D., Lalonde, J., and Steffen, A.: The Arctic: a sink for mercury, Tellus, 56B, 397-403, 2004.

Barrie, L. A., Bottenheim, J. W., Schnell, R. C., Crutzen, P. J., and Rasmussen, R. A.: Ozone destruction and photochemical reactions at polar sunrise in the lower Arctic atmosphere, Nature, 334, 138-141, 1988.

Barrie, L. A., Bottenheim, J. W., and Hart, W. R.: Polar Sunrise Experiment 1992 (PSE 1992): Preface, J. Geophys. Res., 99, 25313-25314, 1994.

Begoin, M., Richter, A., Weber, M., Kaleschke, L., Tian-Kunze, X., Stohl, A., Theys, N., and Burrows, J. P.: Satellite observations of long range transport of a large $\mathrm{BrO}$ plume in the Arctic, Atmos. Chem. Phys., 10, 6515-6526, doi:10.5194/acp-10-65152010, 2010.

Boersma, K. F., Eskes, H. J., and Brinksma, E. J.: Error analysis for tropospheric $\mathrm{NO}_{2}$ retrieval from space, J. Geophys. Res., 109, D04311, doi:10.1029/2003JD003962, 2004.

Bottenheim, W., Barrie, L. A., Atlas, E., Heidt, L. E., Niki, H., Rasmussen, R. A., and Shepson, P. B.: Depletion of lower tropospheric ozone during Arctic spring: The polar sunrise experiment 1988, J. Geophys. Res., 95, 18555-18568, 1990.

Bovensmann, H., Burrows, J. P., Buchwitz, M., Frerick, J., Noël, S., Rozanov, V. V., Chance, K. V., and Goede, A. P. H.: SCIAMACHY: Mission Objectives and Measurement Modes, J. Atmos. Sci., 56, 127-150, 1999.

Brock, C. A., Cozic, J., Bahreini, R., Froyd, K. D., Middlebrook, A. M., McComiskey, A., Brioude, J., Cooper, O. R., Stohl, A., Aikin, K. C., de Gouw, J. A., Fahey, D. W., Ferrare, R. A., Gao, R.-S., Gore, W., Holloway, J. S., Hübler, G., Jefferson, A., Lack, D. A., Lance, S., Moore, R. H., Murphy, D. M., Nenes, A., Novelli, P. C., Nowak, J. B., Ogren, J. A., Peischl, J., Pierce, R. B., Pilewskie, P., Quinn, P. K., Ryerson, T. B., Schmidt, K. S., Schwarz, J. P., Sodemann, H., Spackman, J. R., Stark, H., Thomson, D. S., Thornberry, T., Veres, P., Watts, L. A., Warneke, C., and Wollny, A. G.: Characteristics, sources, and transport of aerosols measured in spring 2008 during the aerosol, radiation, and cloud processes affecting Arctic Climate (ARCPAC) Project, Atmos. Chem. Phys., 11, 2423-2453, doi:10.5194/acp-11-24232011, 2011.

Callies, J., Corpaccioli, E., Hahne, A., and Lefebvre, A.: GOME-2 - Metop's second- generation sensor for operational ozone monitoring, ESA Bulletin-European Space Agency, 102, 28-36, 2000.
Chance, K.: Analysis of BrO Measurements from the Global Ozone Monitoring Experiment, Geophys. Res. Lett., 25, 3335-3338, 1998.

Claas, J., Braak R., and Kroon, M.: Row anomaly: introduction and flagging, OMI Science Team Meeting, De Bilt, The Netherlands, June 2010.

De Smedt, I., Müller, J.-F., Stavrakou, T., van der A, R., Eskes, H., and Van Roozendael, M.: Twelve years of global observations of formaldehyde in the troposphere using GOME and SCIAMACHY sensors, Atmos. Chem. Phys., 8, 4947-4963, doi:10.5194/acp-8-4947-2008, 2008.

Dibb, J. E., Ziemba, L. D., Luxford, J., and Beckman, P.: Bromide and other ions in the snow, firn air, and atmospheric boundary layer at Summit during GSHOX, Atmos. Chem. Phys., 10, 99319942, doi:10.5194/acp-10-9931-2010, 2010.

Dikty, S., Richter, A., Weber, M., Noel, S., Wittrock, F. Bovensmann, H., Munro, R., Lang, R., and Burrows, J. P.: GOME-2 optical degradation as seen in level 2 data time series (2007-2010; $\mathrm{BrO}, \mathrm{NO}_{2}, \mathrm{HCHO}, \mathrm{H}_{2} \mathrm{O}$, and $\mathrm{O}_{3}$ ), EGU General Assembly, Vienna, Austria, available at: http://www.doas-bremen.de/posters/ egu_2011_dikty.pdf, April 2011.

Deutsches Zentrum für Luft und Raumfahrt e.V.: Algorithm Theoretical Basis Document for GOME-2 Total Column Products of Ozone, Minor Trace Gases, and Cloud Properties, Oberpfaffenhofen, Germany, 2009.

Donohoue, D., Carlson, D., and Simpson, W. R.: Rapid methods for inversion of MAXDOAS elevation profiles to surface-associated box concentrations, visibility, and heights: application to analysis of Arctic BrO events, Atmos. Meas. Tech. Discuss., 3, 46454674, doi:10.5194/amtd-3-4645-2010, 2010.

Dorf, M., Butz, A., Camy-Peyret, C., Chipperfield, M. P., Kritten, L., and Pfeilsticker, K.: Bromine in the tropical troposphere and stratosphere as derived from balloon-borne $\mathrm{BrO}$ observations, Atmos. Chem. Phys., 8, 7265-7271, doi:10.5194/acp-8-72652008, 2008.

Douglas, T. A., Sturm, M., Simpson, W. R., Brooks, S., Lindberg, S., and Perovich, D.: Elevated mercury measured in snow and frost flowers near Arctic sea ice leads, Geophys. Res. Lett., 32, L04502, doi:10.1029/2004GL022132, 2005.

Fan, S.-M. and Jacob, D. J.: Surface ozone depletion in Arctic spring sustained by bromine reactions on aerosols, Nature, 359, 522-524, 1992.

Fitzenberger, R., Bösch, H., Camy-Peyret, C., Chipperfield, M. P., Harder, H., Platt, U., Sinnhuber, B.-M., Wagner, T., and Pfeilsticker, K.: First profile measurements of tropospheric BrO, Geophys. Res. Lett., 27, 2921-2924, 2000.

Frieß, U., Chipperfield, M. P., Harder, H., Otten, C., Platt, U., Pyle, J., Wagner, T., and Pfeilsticker, K.: Intercomparison of measured and modelled BrO slant column amounts for the Arctic winter and spring 1994/95, Geophys. Res. Lett., 26, 1861-1864, 1999.

Frieß, U., Sihler, H., Sander, R., Pöhler, D., Yilmaz, S., and Platt, U.: The vertical distribution of $\mathrm{BrO}$ and aerosols in the Arctic: Measurements by active and passive differential optical absorption spectroscopy, J. Geophys. Res., 116, D00R04, doi:10.1029/2011JD015938, 2011.

Garcia, R. R., Marsh, D. R., Kinnison, D. E., Boville, B. A., and Sassi, F.: Simulations of secular trends in the middle atmosphere, 1950-2003, J. Geophys. Res., 112, D09301, doi:10.1029/2006JD007485, 2007. 
GOME Users Manual, ESA Special Publication SP-1182, ESTEC, Noordwijk, The Netherlands, 1995.

Hausmann, M. and Platt, U.: Spectroscopic measurement of bromine oxide and ozone in the high Arctic during Polar Sunrise Experiment 1992, J. Geophys. Res., 99, 25399-25413, 1994.

Hegels, E., Crutzen, P. J., Klupfel, T., Perner, D., and Burrow, J. P.: Global distribution of atmospheric bromine-monoxide from GOME on earth observing satellite ERS-2, Geophys. Res. Lett., 25, 3127-3130, 1998.

Hendrick, F., Van Roozendael, M., Chipperfield, M. P., Dorf, M., Goutail, F., Yang, X., Fayt, C., Hermans, C., Pfeilsticker, K., Pommereau, J.-P., Pyle, J. A., Theys, N., and De Mazière, M.: Retrieval of stratospheric and tropospheric BrO profiles and columns using ground-based zenith-sky DOAS observations at Harestua, $60^{\circ} \mathrm{N}$, Atmos. Chem. Phys., 7, 4869-4885, doi:10.5194/acp-7-4869-2007, 2007.

Hendrick, F., Johnston, P. V., De Maziére, Fayt, C., Hermans, C., Kreher, K., Theys, N., Thomas, A., and Van Roozendael, M.: One-decade trend analysis of stratospheric $\mathrm{BrO}$ over Harestua $\left(60^{\circ} \mathrm{N}\right)$ and Lauder $\left(45^{\circ} \mathrm{S}\right)$ reveals a decline, Geophys. Res. Lett., 35, L14801, doi:10.1029/2008GL034154, 2008.

Holmes, C. D., Jacob, D. J., Corbitt, E. S., Mao, J., Yang, X., Talbot, R., and Slemr, F.: Global atmospheric model for mercury including oxidation by bromine atoms, Atmos. Chem. Phys., 10, 12037-12057, doi:10.5194/acp-10-12037-2010, 2010.

Hönninger and Platt, U.: Observations of $\mathrm{BrO}$ and its vertical distribution during surface ozone depletion at Alert, Atmos. Environ., 36, 2481-2489, 2002.

Hönninger, G., Leser, H., Sebastián, O., and Platt, U.: Groundbased measurements of halogen oxides at the Hudson Bay by longpath DOAS and passive MAX-DOAS, Geophys. Res. Lett., 31, L04111, doi:10.1029/2003GL018982, 2004b.

Jones, A. E., Anderson, P. S., Wolff, E. W., Turner, J., Rankin, A. M., and Colwell, S. R.: A role for newly forming sea ice in springtime polar tropospheric ozone loss? Observational evidence from Halley station, Antarctica, J. Geophys. Res., 111, D08306, doi:10.1029/2005JD006566, 2006.

Jones, A. E., Anderson, P. S., Begoin, M., Brough, N., Hutterli, M. A., Marshall, G. J., Richter, A., Roscoe, H. K., and Wolff, E. W.: $\mathrm{BrO}$, blizzards, and drivers of polar tropospheric ozone depletion events, Atmos. Chem. Phys., 9, 4639-4652, doi:10.5194/acp-94639-2009, 2009.

Jones, A. E., Anderson, P. S., Wolff, E. W., Roscoe, H. K., Marshall, G. J., Richter, A., Brough, N., and Colwell, S. R.: Vertical structure of Antarctic tropospheric ozone depletion events: characteristics and broader implications, Atmos. Chem. Phys., 10, 7775-7794, doi:10.5194/acp-10-7775-2010, 2010.

Jacob, D. J., Crawford, J. H., Maring, H., Clarke, A. D., Dibb, J. E., Emmons, L. K., Ferrare, R. A., Hostetler, C. A., Russell, P. B., Singh, H. B., Thompson, A. M., Shaw, G. E., McCauley, E., Pederson, J. R., and Fisher, J. A.: The Arctic Research of the Composition of the Troposphere from Aircraft and Satellites (ARCTAS) mission: design, execution, and first results, Atmos. Chem. Phys., 10, 5191-5212, doi:10.5194/acp-10-5191-2010, 2010.

Kaleschke, L., Richter, A., Burrows, J., Afe, O., Heygster, G., Notholt, J., Rankin, A. M., Roscoe, H. K., Hollwedel, J., Wagner, T., and Jacobi, H.-W.: Frost flowers on sea ice as a source of sea salt and their influence on tropospheric halogen chemistry, Geophys. Res. Lett., 31, L16114, doi:10.1029/2004GL020655,
2004.

Kalnay, E., Kanamitsu, M., Kistler, R., Collins, W., Deaven, D., Gandin L., Iredell, M., Saha, S., White, G., Woollen, J., Zhu, Y., Leetmaa, A., Reynolds, R., Chelliah, M., Ebisuzaki, W., Higgins, W., Janowiak, J., Mo, K. C., Ropelewski, C., Wang, J., Jenne, R., and Joseph, D.:The NCEP/NCAR 40-year reanalysis project, B. Am. Meteorol. Soc., 77, 437-470, 1996.

Koo, J.-H., Wang, Y., Choi, S., Kurosu, T. P., Chance, K., Rozanov, A., Richter, A., Oltmans, S. J., Thompson, A. M., Hair, J. W., Fenn, M. A., Weinheimer, A. J., Ryerson, T. B., MacTavish, D., Shaw, M., Huey, L. G., Liao, J., Dibb, J. E., Neuman, A., Pierce, B., Natarajan, M., and Al-Saadi, J.: Characteristics of tropospheric ozone depletion events in the Arctic spring, in preparation, 2012.

Kovalenko, L. J., Livesey, N. J., Salawitch, R. J., Camy-Peyret, C., Chipperfield, M. P., Cofield, R. E., Dorf, M., Drouin, B. J., Froidevaux, L., Fuller, R., A., Goutail, F., Jarnot, R. F., Jucks, K., Knosp, B. W., Lambert, A., MacKenzie, I. A., Pfeilsticker, K., Pommereau, J.-P., Read, W. G., Santee, M. L., Schwartz, M, J., Snyder, W. V., Stachnik, R., Stek. P. C., Wagner, P. A., and Waters, J. W.: Validation of Aura Microwave Limb Sounder BrO obdservations in the stratosphere, J. Geophys. Res., 112, D24S41, doi:10.1029/2007JD008817, 2007.

Kreher, K., Johnston, P. V., Wood, S. W., Nardi, B., and Platt, U.: Ground-based measurements of tropospheric and stratospheric $\mathrm{BrO}$ at Arrival Heights, Antarctica, Geophys. Res. Lett., 24, 3021-3024, 1997.

Kurosu, T. and Chance, K.: OMBRO Readme file, https://www.cfa.harvard.edu/ tkurosu/SatelliteInstruments/ OMI/PGEReleases/READMEs/OMBRO_v300_README.pdf, 2011.

Lehrer, E., Hönninger, G., and Platt, U.: A one dimensional model study of the mechanism of halogen liberation and vertical transport in the polar troposphere, Atmos. Chem. Phys., 4, 2427 2440, doi:10.5194/acp-4-2427-2004, 2004.

Levelt, P. F., van den Oord, G. H. J., Dobber, M. R., Mälkki, A., Visser, H., de Vries, J., Stammes, P., Lundell, J., and Saari, H.: The Ozone Monitoring Instrument, IEEE T. Geosci. Remote Sens., 44, 1093-1101, doi:10.1109/TGRS.2006.872333, 2006.

Liao, J., Sihler, H., Huey, L. G., Neuman, J. A., Tanner, D. J., Friess, U., Platt, U., Flocke, F. M., Orlando, J. J., Shepson, P. B., Beine, H. J., Weinheimer, A. J., Sjostedt, S. J., Nowak, J. B., Knapp, D. J., Staebler, R. M., Zheng, W., Sander, R., Hall, S. R., and Ullmann, K.: A comparison of Arctic BrO measurements by chemical ionization mass spectrometry and long path-differential optical absorption spectroscopy, J. Geophys. Res.-Atmos., 116, D00r02, doi:10.1029/2010jd014788, 2011.

Liao, J., Huey, L. G., Scheuer, E., Dibb, J. E., Stickel, R. E., Tanner, D. J., Neuman, J. A., Nowak, J. B., Choi, S., Wang, Y., Salawitch, R. J., Canty, T., Chance, K., Kurosu, T., Suleiman, R., Weinheimer, A. J., Shetter, R. E., Fried, A., Brune, W., Anderson, B., Zhang, X., Chen, G., Crawford, J., Hecobian, A., and Ingall, E. D.: Characterization of soluble bromide measurements and a case study of BrO observations during ARCTAS, Atmos. Chem. Phys. Discuss., 11, 26999-27030, doi:10.5194/acpd-1126999-2011, 2011.

Livesey, N. J., Kovalenko L. J., Salawitch, R. J., MacKenzie, I. A., Chipperfield, M. P., Read, W. G., Jarnot, R. F., and Waters, J. W.: EOS Microwave Limb Sounder observations of upper strato- 
spheric BrO: Implications for total bromine, Geophys. Res. Lett., 33, L20817, doi:10.1029/2006GL026930, 2006.

Lu, J. Y., Schroeder, W. H., Barrie, L. A., Steffen, A., Welch, H. E., Martin, K., Lockhart, L., Hunt, R. V., Boila, G., and Richter, A.: Magnification of atmospheric mercury deposition to polar regions in springtime: the link to tropospheric ozone depletion chemistry, Geophys. Res. Lett., 28, 3219-3222, 2001.

Martinez, M., Arnold, T., and Perner, D.: The role of bromine and chlorine chemistry for arctic ozone depletion events in $\mathrm{Ny}$ Ålesund and comparison with model calculations, Ann. Geophys., 17, 941-956, doi:10.1007/s00585-999-0941-4, 1999.

McElroy, C. T., McLinden, C. A., and McConnell, J. C.: Evidence for bromine monoxide in the free troposphere during the Arctic polar sunrise, Nature, 397, 338-341, 1999.

Munro, R., Eisinger, M., Anderson, C., Callies, J., Corpaccioli, E., Lang, R., Lefebvre, A., Livschitz, Y., and Albinana, A. P.: GOME-2 on MetOp, in: Proc. of The 2006 EUMETSAT Meteorological Satellite Conference, Helsinki, Finland, 12-16 June 2006, EUMETSAT, p. 48, 2006.

Neuman, J. A., Nowak, J. B., Huey, L. G., Burkholder, J. B., Dibb, J. E., Holloway, J. S., Liao, J., Peischl, J., Roberts, J. M., Ryerson, T. B., Scheuer, E., Stark, H., Stickel, R. E., Tanner, D. J., and Weinheimer, A.: Bromine measurements in ozone depleted air over the Arctic Ocean, Atmos. Chem. Phys., 10, 6503-6514, doi:10.5194/acp-10-6503-2010, 2010.

Nolin, A., Armstrong, R. L., and Maslanik, J.: Near Real-Time SSM/I EASE-Grid Daily Global Ice Concentration and Snow Extent, Jan to Mar 2004 (updated daily), Boulder, CO, USA, National Snow and Ice Data Center, Digital media, 1998.

Palmer, P. I., Jacob, D. J., Chance, K., Martin, R. V., Spurr, R. J. D., Kurosu, T. P., Bey, I., Yantosca, R., Fiore, A., and Li, Q.: Airmass factor formulation for spectroscopic measurements from satellites: application to formaldehyde retrievals from GOME, J. Geophys. Res., 106, 14539-14550, doi:10.1029/2000JD900772, 2001.

Pfeilsticker, K., Sturges, W. T., Bosch, H., Camy-Peyret, C., Chipperfield, M. P., Engel, A., Fitzenberger, R., Muller, M., Payan, S., and Sinnhuber, B. M.: Lower stratospheric organic and inorganic bromine budget for the Arctic winter 1998/99, Geophys. Res. Lett., 27, 3305-3308, 2000

Platnick, S., King, M. D., Ackerman, S. A., Menzel, W. P., Baum, B. A., Riedi, J. C., and Frey, R. A.: The MODIS cloud products: algorithms and examples from Terra, IEEE T. Geosci. Remote, 41, 459-473, 2003.

Platt, U. and Hönninger, G.: The role of halogen species in the troposphere, Chemosphere, 52, 325-338, 2003.

Prados-Roman, C., Butz, A., Deutschmann, T., Dorf, M., Kritten, L., Minikin, A., Platt, U., Schlager, H., Sihler, H., Theys, N., Van Roozendael, M., Wagner, T., and Pfeilsticker, K.: Airborne DOAS limb measurements of tropospheric trace gas profiles: case studies on the profile retrieval of $\mathrm{O}_{4}$ and $\mathrm{BrO}$, Atmos. Meas. Tech., 4, 1241-1260, doi:10.5194/amt-4-1241-2011, 2011.

Pundt, I., Pommereau, J. P., Chipperfield, M. P., Van Roozendael, M., and Goutail, F.: Climatology of the stratospheric $\mathrm{BrO}$ vertical distribution by balloon-borne UV-visible spectrometry, J. Geophys. Res., 107, 4806, doi:10.1029/2002JD002230, 2002.

Richter, A., Wittrock, F., Eisinger, M., and Burrows, J. P.: GOME Observations of Tropospheric BrO in Northern Hemispheric Spring and Summer 1997, Geophys. Res. Lett., 25, 2683-2686,
1998.

Ridley, B. A., Atlas, E. L., Montzka, D. D., Browell, E. V., Cantrell, C. A., Blake, D. R., Blake, N. J., Cinquini, L., Coffey, M. T., Em- mons, L. K., Cohen, R. C., DeYoung, R. J., Dibb, J. E., Eisele, F. L., Flocke, F. M., Fried, A., Grahek, F. E., Grant, W. B., Hair, J. W., Hannigan, J., Heikes, B. J., Lefer, B. L., Mauldin, R. L., Moody, J. L., Shetter, R. E., Snow, J. A., Talbot, R. W., Thornton, J. A., Walega, J. G., Weinheimer, A. J., Wert, B. P., and Wimmers, A. J.: Ozone Depletion Events Observed in the High Latitude Surface Layer During the TOPSE Aircraft Program, J. Geophys. Res., 108, 8356, doi:10.1029/2001JD001507, 2003.

Rienecker, M. M., Suarez, M. J., and Todling, R.: The GEOS- 5 data assimilation system - Documentation of versions 5.0.1, 5.1.0, and 5.2.0. NASA Tech. Memo. 2007-104606, vol. 27, edited by: Suarez, M. J., 2007.

Rozanov, A., Rozanov, V., Buchwitz, M., Kokhanovsky, A., and Burrows, J. P.: SCIATRAN 2.0 - a new radiative transfer model for geophysical applications, Adv. Space Res., 36, 1015-1019, 2005.

Rozanov, A., Kühl, S., Doicu, A., McLinden, C., Pukite, J., Bovensmann, H., Burrows, J. P., Deutschmann, T., Dorf, M., Goutail, F., Grunow, K., Hendrick, F., von Hobe, M., Hrechanyy, S., Lichtenberg, G., Pfeilsticker, K., Pommereau, J. P., Van Roozendael, M., Stroh, F., and Wagner, T.: BrO vertical distributions from SCIAMACHY limb measurements: comparison of algorithms and retrieval results, Atmos. Meas. Tech., 4, 1319-1359, doi:10.5194/amt-4-1319-2011, 2011.

Saiz-Lopez, A., Mahajan, A. S., Salmon, R. A., Bauguitte, S. J.B., Jones, A. E., Roscoe, H. K., and Plane, J. M. C.: Boundary layer halogens in coastal Antarctica, Science, 317, 348-351, doi:10.1126/science.1141408, 2007.

Salawitch, R. J., Weisenstein, D. K., Kovalenko, L. J., Sioris, C. E., Wennberg, P. O., Chance, K., Ko, M. K. W., and McLinden, C. A.: Sensitivity of ozone to bromine in the lower stratosphere, Geophys. Res. Lett., 32, L05811, doi:10.1029/2004GL021504, 2005.

Salawitch, R., Canty, T., Kurosu, T., Chance, K., Liang, Q., da Silva, A., Pawson, S., Nielsen, J. E., Rodriguez, J. M., Bhartia, P. K., Liu, X., Huey, L. G., Liao, J., Stickel, R. E., Tanner, D. J., Dibb, J. E., Simpson, W. R., Donohoue, D., Weinheimer, A., Flocke, F., Knapp, D., Montzka, D., Neuman, J. A., Nowak, J. B., Ryerson, T. B., Oltmans, S., Blake, D. R., Atlas, E. L., Kinnison, D. E., Tilmes, S., Pan, L. L., Hendrick, F., Van Roozendael., M., Kreher, K., Johnston, P. V., Gao, R. S., Johnson, B., Bui, T. P., Chen, G., Pierce, R. B., Crawford, J. H., and Jacob, D. J.: A new interpretation of total column BrO during Arctic spring, Geophys. Res. Lett., 37, L21805, doi:10.1029/2010GL043798, 2010.

Sander, S. P., Friedl, R. R., Golden, D. M., Kurylo, M. J., Moortgat, G. K., Keller-Rudek, H., Wine, P. H., Ravishankara, A. R., Kolb, C. E., Molina, M. J., Finlayson-Pitts, B. J., Huie, R. E., and Orkin, V. L.: Chemical Kinetics and Photochemical Data for Use in Atmospheric Studies - Evaluation Number 15, NASA JPL Publication 06-2, Jet Propulsion Laboratory, California Institute of Technology, Pasadena, CA, USA, 2006.

Schroeder, W. H., Anlauf, K. G., Barrie, L. A., Lu, J. Y., Steffen, A., Schneeberger, D. R., and Berg, T.: Arctic springtime depletion of mercury, Nature, 394, 331-332, 1998.

Schofield, R., Kreher, K., Connor, B. J., Johnston, P. V., Thomas, 
A., Shooter, D., Chipperfield, M. P., Rodgers, C. D., and Mount, G. H.: Retrieved tropospheric and stratospheric BrO columns over Lauder, New Zealand, J. Geophys. Res., 109, D14304, doi:10.1029/2003JD004463, 2004.

Schofield, R., Johnston, P. V., Thomas, A., Kreher, K., Connor, B. J., Wood, S., Shooter, D., Chipperfield, M. P., Richter, A., von Glasow, R., and Rodgers, C. D.: Tropospheric and stratospheric BrO columns over Arrival Heights, Antartica, 2002, J. Geophys. Res., 111, D22310, doi:10.1029/2005JD007022, 2006.

Shinozuka, Y., Redemann, J., Livingston, J. M., Russell, P. B., Clarke, A. D., Howell, S. G., Freitag, S., O’Neill, N. T., Reid, E. A., Johnson, R., Ramachandran, S., McNaughton, C. S., Kapustin, V. N., Brekhovskikh, V., Holben, B. N., and McArthur, L. J. B.: Airborne observation of aerosol optical depth during ARCTAS: vertical profiles, inter-comparison and fine-mode fraction, Atmos. Chem. Phys., 11, 3673-3688, doi:10.5194/acp-11-36732011, 2011.

Simpson, W. R., Carlson, D., Hönninger, G., Douglas, T. A., Sturm, M., Perovich, D., and Platt, U.: First-year sea-ice contact predicts bromine monoxide $(\mathrm{BrO})$ levels at Barrow, Alaska better than potential frost flower contact, Atmos. Chem. Phys., 7, 621-627, doi:10.5194/acp-7-621-2007, 2007a.

Simpson, W. R., von Glasow, R., Riedel, K., Anderson, P., Ariya, P., Bottenheim, J., Burrows, J., Carpenter, L. J., Frieß, U., Goodsite, M. E., Heard, D., Hutterli, M., Jacobi, H.-W., Kaleschke, L., Neff, B., Plane, J., Platt, U., Richter, A., Roscoe, H., Sander, R., Shepson, P., Sodeau, J., Steffen, A., Wagner, T., and Wolff, E.: Halogens and their role in polar boundary-layer ozone depletion, Atmos. Chem. Phys., 7, 4375-4418, doi:10.5194/acp-74375-2007, 2007b.

Sinnhuber, B.-M., Rozanov, A., Sheode, N., Afe, O. T., Richter, A., Sinnhuber, M., Wittrock, F., Stiller, G. P., von Clarmann, T., Linden, A., and Burrows, J. P.: Global observations of stratospheric bromine monoxide from SCIAMACHY, Geophys. Res. Lett., 32, L20810, doi:10.1029/2005GL023839, 2005.

Sioris, C. E., Kovalenko, L. J., McLinden, C. A., Salawitch, R. J., Van Roozendael, M., Goutail, F., Dorf, M., Pfeilsticker, K., Chance, K., von Savigny, C., Liu, X., Kurosu, T. P., Pommereau, J.-P., Boesch, H., and Frerick, J.: Latitudinal and vertical distribution of bromine monoxide in the lower stratosphere from Scanning Imaging Absorption Spectrometer for Atmospheric Chartography limb scattering measurements, J. Geophys. Res., 111, D14301, doi:10.1029/2005JD006479, 2006.

SPARC Report on the Evaluation of Chemistry-Climate Models, edited by: Eyring, V., Shepherd, T. G., and Waugh, D. W., SPARC Report No. 5, WCRP-132, WMO/TD-No. 1526, http: //www.atmosp.physics.utoronto.ca/SPARC, 2010.

Spurr, R. J. D., Kurosu, T. P., and Chance, K.: A linearized discrete ordinate radiative transfer model for atmospheric remote sensing retrieval, J. Quant. Spectrosc. Ra., 68, 689-735, 2001.

Theys, N., Van Roozendael, M., Hendrick, F., Fayt, C., Hermans, C., Baray, J.-L., Goutail, F., Pommereau, J.-P., and De Mazière, M.: Retrieval of stratospheric and tropospheric BrO columns from multi-axis DOAS measurements at Reunion Island $\left(21^{\circ} \mathrm{S}\right.$, $56^{\circ}$ E), Atmos. Chem. Phys., 7, 4733-4749, doi:10.5194/acp-74733-2007, 2007.

Theys, N., Van Roozendael, M., Errera, Q., Hendrick, F., Daerden, F., Chabrillat, S., Dorf, M., Pfeilsticker, K., Rozanov, A., Lotz, W., Burrows, J. P., Lambert, J.-C., Goutail, F., Roscoe, H. K., and De Mazière, M.: A global stratospheric bromine monoxide climatology based on the BASCOE chemical transport model, Atmos. Chem. Phys., 9, 831-848, doi:10.5194/acp-9-831-2009, 2009.

Theys, N., Van Roozendael, M., Hendrick, F., Yang, X., De Smedt, I., Richter, A., Begoin, M., Errera, Q., Johnston, P. V., Kreher, K., and De Mazière, M.: Global observations of tropospheric BrO columns using GOME-2 satellite data, Atmos. Chem. Phys., 11, 1791-1811, doi:10.5194/acp-11-1791-2011, 2011.

Toyota, K., McConnell, J. C., Lupu, A., Neary, L., McLinden, C. A., Richter, A., Kwok, R., Semeniuk, K., Kaminski, J. W., Gong, S.-L., Jarosz, J., Chipperfield, M. P., and Sioris, C. E.: Analysis of reactive bromine production and ozone depletion in the Arctic boundary layer using 3-D simulations with GEM-AQ: inference from synoptic-scale patterns, Atmos. Chem. Phys., 11, 3949-3979, doi:10.5194/acp-11-3949-2011, 2011.

Tuckermann, M., Ackermann, R., Golz, C., Lorenzen-Schmidt, H., Senne, T., Stutz, J., Trost, B., Unold, W., and Platt, U.: DOAS-observation of halogen radical-catalysed Arctic boundary layer ozone destruction during the ARCTOC-campaigns 1995 and 1996 in Ny-Ålesund, Spitsbergen, Tellus, 49B, 533-555, 1997.

Van Roozendael, M., Wagner, T., Richter, A., Pundt, I., Arlan- der, D. W., Burrows, J. P., Chipperfield, M., Fayt, C., Johnston, P. V., Lambert, J. C., Kreher, K., Pfeilsticker, K., Platt, U., Pommereau, J. P., Sinnhuber, B. M., Tornkvist, K. K., and Wittrock, F.: Intercomparison of $\mathrm{BrO}$ measurements from ERS-2 GOME, ground-based and balloon platforms, in: Remote Sensing Of Trace Constituents In The Lower Stratosphere, Troposphere And The Earth's Surface: Global Observations, Air Pollution And The Atmospheric Correction, vol. 29, Adv. Space Res., 11, 1661-1666, 2002.

Vasilkov, A. P., Joiner, J., Spurr, R. J. D., Bhartia, P. K., Levelt, P., and Stephens, G.: Evaluation of the OMI cloud pressures derived from rotational Ramanscattering by comparisons with other satellite data and radiative transfer simulations, J. Geophys. Res., 113, D15S19, doi:10.1029/2007JD008689, 2008.

Vasilkov, A. P., Joiner, J., Haffner, D., Bhartia, P. K., and Spurr, R. J. D.: What do satellite backscatter ultraviolet and visible spectrometers see over snow and ice? A study of clouds and ozone using the A-train, Atmos. Meas. Tech., 3, 619-629, doi:10.5194/amt-3-619-2010, 2010.

Wagner, T. and Platt, U.: Satellite mapping of enhanced BrO concentrations in the troposphere, Nature, 395, 486-490, 1998.

Wagner, T., Leue, C., Wenig, M., Pfeilsticker, K., and Platt, U.: Spatial and temporal distribution of enhanced boundary layer $\mathrm{BrO}$ concentrations measured by the GOME instrument aboard ERS2, J. Geophys. Res., 106, 24225-24235, 2001.

Wagner, T., Ibrahim, O., Sinreich, R., Frieß, U., von Glasow, R., and Platt, U.: Enhanced tropospheric BrO over Antarctic sea ice in mid winter observed by MAX-DOAS on board the research vessel Polarstern, Atmos. Chem. Phys., 7, 3129-3142, doi:10.5194/acp-7-3129-2007, 2007.

Wahner A., Ravishankara, A. R., Sander S. P., Friedl R. R.: Absorption cross-section of BrO between 312 and $385 \mathrm{~nm}$ at 298 and 223-K, Chem. Phys. Lett., 152, 507-512, 1988.

Wamsley, P. R., Elkins, J. W., Fahey, D. W., Dutton, G. S., Volk, C. M., Myers, R. C., Montzka, S. A., Butler, J. H., Clarke, A. D., Fraser, P. J., Steele, L. P., Lucarelli, M. P., Atlas, E. L., Schauffler, 
S. M., Blake, D. R., Rowland, F. S., Sturges, W. T., Lee, J. M., Penkett, S. A., Engel, A., Stimpfle, R. M., Chan, K. R., Weisenstein, D. K., Ko, M. K. W., and Salawitch, R. J.: Distribution of halon-1211 in the upper troposphere and lower stratosphere and the 1994 bromine budget, J. Geophys. Res., 103, 1513-1526, doi:10.1029/97JD02466, 1998.

Wilmouth, D. M., Hanisco, T. F., Donahue, N. M., and Anderson, J. G.: Fourier transform ultraviolet spectroscopy of the A (2) $\mathrm{Pi}(3 / 2)$ $<-\mathrm{X}$ (II3/2)-I-2 transition of BrO, J. Phys. Chem. A, 103, 8935$8945,1999$.

WMO (World Meteorological Organization), Scientific Assessment of Ozone Depletion: 2002, Global Ozone Research and Monitoring Project - Report No. 47, Geneva, Switzerland, 2003.

WMO (World Meteorological Organization), Scientific Assessment of Ozone Depletion: 2006, Global Ozone Research and Monitoring Project - Report No. 50, Geneva, Switzerland, 2007.
WMO (World Meteorological Organization), Scientific Assessment of Ozone Depletion: 2010, Global Ozone Research and Monitoring Project - Report No. 52, 516 pp., Geneva, Switzerland, 2011.

Yang, X., Pyle, J. A., and Cox, R. A.: Sea salt aerosol production and bromine release: Role of snow on sea ice, Geophys. Res. Lett., 35, L16815, doi:10.1029/2008GL034536, 2008.

Zeng, T., Wang, Y., Chance, K., Browell, E. V., Ridley, B. A., and Atlas, E. L.: Widespread persistent near-surface ozone depletion at northern high latitudes in spring, Geophys. Res. Lett., 30, 2298, doi:10.1029/2003GL018587, 2003.

Zeng, T., Wang, Y., Chance, K., Blake, N., Blake, D., and Ridley, B.: Halogen-driven low-altitude $\mathrm{O}_{3}$ and hydrocarbon losses in spring at northern high latitudes, J. Geophys. Res., 111, D17313, doi:10.1029/2005JD006706, 2006. 